\title{
Quantifying Critical Success Factors (CSFs) in Management of Investment-Construction Projects: Insights from Bayesian Model Averaging
}

\author{
Janusz Sobieraj ${ }^{1}$ (D) and Dominik Metelski ${ }^{2, *(D)}$ \\ 1 Department of Building Engineering, Warsaw University of Technology, 00-637 Warsaw, Poland; \\ jsob@il.pw.edu.pl \\ 2 Faculty of Economics and Management Sciences, University of Granada, 18071 Granada, Spain \\ * Correspondence: dmetelski@ugr.es
}

Citation: Sobieraj, J.; Metelski, D. Quantifying Critical Success Factors (CSFs) in Management of Investment-Construction Projects: Insights from Bayesian Model Averaging. Buildings 2021, 11, 360. https://doi.org/10.3390/

buildings 11080360

Academic Editor: Silvio Melhado

Received: 8 July 2021

Accepted: 13 August 2021

Published: 17 August 2021

Publisher's Note: MDPI stays neutral with regard to jurisdictional claims in published maps and institutional affiliations.

Copyright: (c) 2021 by the authors. Licensee MDPI, Basel, Switzerland. This article is an open access article distributed under the terms and conditions of the Creative Commons Attribution (CC BY) license (https:// creativecommons.org/licenses/by/ $4.0 /)$.

\begin{abstract}
The problem with evaluating investment projects is that there are many factors that determine the degree of their successful conclusion. Consequently, there has been an active debate for years as to which critical success factors (CSFs) contribute most to the performance of construction projects. This is because the practice of empirical research is based on two steps: first, researchers choose a particular model from the space of all possible models, and second, they act as if the chosen model is the only one that fits the data and describes the phenomenon under study. Hence, there are many CSF lists that can be found in the literature, owing to the uncertainty at the model selection stage, which is usually ignored. Alternatively, model averaging accounts for this model uncertainty. In this study, the Bayesian model averaging and data from a survey of Polish construction managers were used to investigate the potential of 28 factors describing a diverse set of characteristics in explaining the performance of construction projects in Poland. Determinants of successful completion of investment projects are categorized by their level of evidential strength, which is derived from posterior inclusion probabilities (PIPs), i.e., providing strong, medium and weak evidence.
\end{abstract}

Keywords: construction project management; construction project success; critical success factors (CSFs); Bayesian model averaging

\section{Introduction}

Construction is one of the focal sectors of the Polish economy, with a significant share in GDP. In 2019 alone, the construction market accounted for $6.6 \%$ of Poland's GDP [1], with a total value of PLN 145.5 billion, making it one of the most profitable sectors of the Polish economy (right after retail trade and the industry). Over the last decade, the value of this market has increased by 48\%. In 2019, the construction sector in Poland employed 980 thousand people, which accounted for $6.1 \%$ of all Polish workers. However, this does not mean that the Polish construction market is not struggling with problems [2,3]. Some of them were described in the study by Jaki and Ćwięk [4], e.g., unfavorable legal regulations in the sphere of public procurement (in which the offered price is often taken as a dominant criterion), rising labor costs and the costs of raw materials and construction materials, or inefficient activities of public authorities with regards to the settlement of completed investments. Important issues that hinder the functioning of this market are described by Sobieraj [5] and Górny [6]. According to Sobieraj [5] and Górny [6], the key factors negatively affecting the implementation of investment projects in Poland are primarily of a human nature. They are related to the unavailability of workers with high qualifications and appropriate professional experience; seasonality of employment combined with the lack of properly trained staff; and high rotation of personnel, leading to the employment of young and inexperienced workers. Other important issues include an excessive focus on meeting deadlines, often at the expense of project teams who feel that they are under severe 
time pressure. On top of all of this is the complexity of construction projects, resulting in an increased risk of accidents on sites and budgetary constraints and ensuing recruitment of workers who accept lower wages and whose professional skills are rather dubious $[5,7,8]$.

More importantly, in the BGK report covering the results of the 2019 survey of the Polish construction sector, the perception of the situation in construction by representatives of companies operating in the sector was described as unsatisfactory (National Economy Bank) [7]. Almost half of the project managers (47\%) evaluate it negatively, and only $26 \%$ positively. Ratings differ depending on the size of the company and the sector in which it operates. Interestingly, as many as $84 \%$ of the surveyed companies, especially the large ones, report having unprofitable contracts in their portfolios [3,7]. In order to minimize the losses it ensues, companies usually try to optimize their work schedules, renegotiate prices with suppliers and investors, and use lower-priced materials $[5,8]$.

Another quite common phenomenon in the construction industry are problems with financial liquidity or payment bottlenecks (confirmed by $41 \%$ of surveyed companies and slightly more often by large companies- $47 \%$ of responses). Companies complain about problems with maintaining financial liquidity, which is mainly due to lengthy payment periods, which is caused by extended deadlines for commissioning of investments and difficulties in claiming compensation for additional works [2]. Another issue that causes financing problems for entrepreneurs is the lack of an adequate advance payment system and the inability to provide quick access to working capital financing $[5,7,8](44 \%$ of all responses). Professionals operating in the sector clearly indicate that it is not easy for construction companies to access such financing (whether in the form of loans or contract guarantee lines- $82 \%$ and $71 \%$ of respondents' indications, respectively) $[5,7,9]$.

Moreover, Gudienè et al. [10] and Górny [6] address the phenomenon of a relatively high fragmentation of the Polish construction sector and the high proportion of its subcontracting services, which usually result in poorer coordination and worse management of investment projects. In the case of Polish construction companies, it must be noted that a vast majority of them are micro-enterprises (which account for $97 \%$ of the whole sector), employing up to nine people [7]. This is due to the fact that self-employment is the dominant legal form in the Polish construction industry. Still, large companies account for the largest number of employees. Nonetheless, the high fragmentation of the construction sector usually also entails a number of problems, e.g., less close cooperation practices, the resulting lack of mutual sharing of experience, and a whole range of problems with project financing [5,7]. Garbharran et al. [11] argue that an increasing complexity of construction projects (especially large ones) makes it even more difficult for project managers to bring them to a successful conclusion. Furthermore, success is essential for any business, if only to retain existing customers, attract new ones, and be able to continue to grow.

In the literature, the success of an investment project is referred to in those cases wherein its completion has been achieved "on time, within budget, and according to predefined specification" [12]. The large degree of diversity among construction companies and project teams, however, makes each of them interpret the concept of success in a different way. Al-Tmeemy et al. [13] and Yong and Mustaffa [14,15] note that both the high degree of diversity of construction companies and the uniqueness of individual construction projects make it necessary for construction companies to discuss and reconcile all issues related to investment project success on an individual basis. In other words, it is impossible to treat all projects with one single measure.

Zavadskas et al. [16-18] stress the causality and mutual reinforcement (in the sense of a positive feedback loop) between project successes realized by individual organizations (i.e., construction companies) and the performance of those organizations. This manifests itself in the fact that investment project successes contribute to organizational successes, and the latter later translate into even further project successes [16-18]. Garbharran et al. [11] posit that CSFs are associated with those areas of the investment project that increase the chances of its successful conclusion. 
Many researchers link the successful completion of a project to the selection of the right project leader [5,19-22]. The probability of success can also be improved by developing an effective project strategy [23], which needs to be taken care of and supported by the highest management [24]. Ahmed et al. [25] emphasize that senior management can make an important contribution to successful completion of projects by making competent decisions and hiring competent staff for the right positions. This, in turn, requires the right leadership and managerial qualities, knowledge, skills, and competencies. Ibrahim et al. [26] point to the need for well-integrated teams, which also translates into successful project completion. They identified $15 \mathrm{key}$ indicators of team integration practices in construction projects.

A number of researchers highlight the importance of critical safety factors (related to the construction safety management system) for successful implementation and completion of investment projects [27-29]. These include management support [22,27,28], development and implementation of appropriate safety programs and trainings $[28,30]$, clear objectives [23], enforcement and adequate supervision [28], personal awareness, and adequate communication and teamwork [28,29]. Moreover, Memon et al. [31] point to the importance of cost-efficiency and factors related to effective resource management as important criteria for measuring the success of a construction project. Doloi et al. [32], on the other hand, point out the lack of employee engagement and the resulting delays in construction projects.

According to Ghoddousi and Hosseini [33], productivity and performance of any investment project can be improved by placing emphasis on such areas as planning, materials/tools, construction technologies and methods, supervision systems, corrections, and construction site improvements.

The realization of construction projects tends to be hectic by its nature. In the flurry of tasks, priorities, responsibilities and deliverables, it is relatively easy to lose track and make many mistakes, which may have irreversible negative consequences, e.g., may result in the loss of key clients, reputation, or cause financial losses or even complete market failures $[5,22]$.

A definition of what critical success factors are can be found in the PRINCE2 methodology, which describes them as critical (key) elements of an investment project that are needed to achieve its predetermined mission or objectives [34]. CSFs can be tracked through key performance indicators (KPIs), by means of which one can adequately assess the management of all project elements [22].

There is also a specific reason why critical success factors are so important and should not be underestimated (overlooked). It turns out that a majority of construction projects fail to achieve the objectives of the schedule [35,36]. A significant number of construction project managers do not fully understand the critical success factors behind their projects, and, as a result, they prioritize non-essential tasks over those that really drive project progress [5]. As a result, many construction projects unfortunately go over budget or beyond their deadline.

The investment project comprises a whole sequence of different sets of activities, namely conceptual, analytical, design-wise, economic, legal, financial, and administrative, as well as those related to tender procedures, execution of construction works, commissioning of the completed facilities for operation, and their subsequent use within the warranty and guarantee period [5]. It must be carried out in accordance with the applicable laws, within a defined timeframe, with the use of secured financial resources and ideally should also ensure certain predefined level of quality.

Bringing an investment project to a successful conclusion is a very complicated process, especially in Polish conditions, where there is the aforementioned high fragmentation of the whole sector, and therefore there are many different entities that are involved in a specific construction project. Of course, it does not necessarily mean that construction companies are helpless in light of numerous problems in a very competitive market environment. There are whole sets of decision-support tools and methods for planning and implementing investments, e.g., in areas such as cost-planning, scheduling, time and risk 
management, etc. It is also possible to make use of proven methodologies and standards for implementing investment projects, such as, for example, Prince2 or PMBoK [37]. In fact, Sobieraj [5] enumerates as many as 20 different methodologies and standards recommended by professional construction institutions. Of particular note is, for example, the $\mathrm{PM}^{2}$ methodology developed and supported by the European Commission, which incorporates elements from globally accepted standards and best practices while being light, easy to implement, and suitable for any project. Moreover, new disruptive technologies are emerging, and companies can develop their own knowledge, which allows them to be at the forefront of the competitive construction sector. The construction company itself may also be linked in some way to academia, which can offer it the instrumentality associated with knowledge building and development of new technologies.

Finally, since as many as 35 to $70 \%$ of all projects fail in some way, it is necessary to continuously improve investment project management standards and methodologies, increase knowledge in this regard and search for new solutions that take into account the paradigm of continuous dynamic changes in the market [22]. Successful project completion is mainly the result of a variety of multidirectional and comprehensive activities in the area of the creation of companies' intellectual capital, preparation of flexible plans and schedules, and their posterior implementation. Integration of these elements makes a company's business activities stand out from its competitors and bring the intended market effects. Construction projects have the distinctive feature that each of them is different, which means they are highly individualized. There is a great number of factors that determine the degree of their successful completion [5]. Consequently, there has been an active debate for many years about which CSFs contribute most to the best project performance. Muhammad and Johar [38] argue that construction market is so complex that scientists cannot find consensus with respect to the list of common factors determining the success of construction projects. This is largely due to the practice of empirical research, which boils down to choosing a particular model that, while fitting the data, is only one of thousands of similar models and therefore describes only a part of reality. This does not mean that there do not exist research approaches that address the above-described problem. One such approach is the Bayesian model averaging (BMA), which was used in this study. For example, Kabir et al. [39] argue that the performance of the BMA approach is noticeably better when compared to traditional statistical models, such as, for example, regression models.

In this study, the BMA approach and data from a survey of Polish construction managers were used to investigate the potential of 28 factors describing a diverse set of characteristics in explaining the performance of construction projects in Poland. The structure of the paper is very straightforward. The following part overviews the critical success factors discussed in the literature. The subsequent empirical part focuses on the analytical aspects, data collection, methodology, and the results. The paper ends with the discussion and conclusion sections.

\section{Theoretical Background}

One of the approaches towards addressing the success of an investment project is to focus on the critical success factors that lead to its successful completion [10,22]. The concept of CSFs was first defined by Rockart [40]. To put it simply, these are all the areas that translate into achieved performance of a specific investment project. They have been used, for example, in management information systems, but CSFs are also widely used by industries other than construction [41]. Critical success factors are important because they help project managers to adequately communicate between different project stakeholders, monitor and control the scope, change and risk, identify and prioritize goals and objectives, identify and allocate resources, and remove bottlenecks in knowledgeexchange flows. They also include, for example, adequate risk management [24] and top-management support $[22,27,28]$. 
Over the past few decades, numerous lists of critical success factors have been created. The fact of the matter is that there is a large number of researchers interested in studying the factors influencing the success of an investment project and the criteria for measuring such success $[11,22,42]$. It is worth summarizing what has hitherto been found and confirmed in the literature.

For example, Sayles and Chandler [23] indicate the importance of such CSFs as flexible and timely project planning; key competences of the project manager; adequate communication; control and accountability systems; adequate monitoring at many levels (e.g., country's economic situation on an ongoing basis, monitoring of the environment, monitoring of the emergence of new building technologies, etc.); and involvement of all parties in the project, i.e., employees, management, and stakeholders. Martin [43] prioritizes the role of accurately defining and communicating project goals, selection of the organization's appropriate project philosophy, management support, organization and delegation of authority, selection of an adequate and competent project team, provision of sufficient resources, provision of information and control mechanisms, and mandatory planning and reviews. Cleland and King [44], on the other hand, address such CSFs as a detailed and concise project description, pivotal role of the senior management, importance of the financial support, logistical requirements, support of the construction backup facilities, market research, project time schedules, executive development and staff training, manpower and organization, communication and information channels, and project reviews. Baker, Murphy, and Fisher [45] refer to the need for precise and accurate objectives, commitment of project teams in reaching project objectives, appointment of the local project manager, sufficient project funding, sufficient project team capacity, accurate estimation of project costs, minimization of difficulties encountered in the initial phase of the project, project planning and control techniques, task orientation, and absence of bureaucracy. Locke [46] stresses the importance of disseminating information about project implementation, delegating authority, appointing a competent project manager, establishing procedures and information flow, establishing project control mechanisms, and organizing cyclical meetings to assess project progress. Sullivan and Harris [47] address the importance of having a specific project strategy that combines individual and group skills to achieve the best balance of resources available at the right time. They also point to the need for engaging major clients in the project management activities at an executive level, as they are the ones who have a view of the project in its holistic context. Pinto [42] refers to such CSFs as project mission, support of the senior management, adequate project plans, time schedules, cooperation with the client, personnel, technical tasks, customer acceptance, monitoring and feedback, good communication, and faults' detection and correction.

Odeyinka and Yusif [48] point to factors related to the client of an investment project, and in particular those related to failure to meet timely financial obligations to contractors and numerous order changes or resulting from resource procurement problems, and uncontrollable external factors. The latter may be caused, for example, by unfavorable weather conditions, random events, strikes, labor disputes and civil unrest, and consultantrelated factors, e.g., late issuance of instructions, incomplete drawings, etc. The Standish Group $[49,50]$ bring up the end-user involvement, support for senior management, precise business objectives, experienced project manager, small milestones, stable basic requirements, competent personnel, proper planning, project ownership, adaptive processes, expert support, high-quality resources, implementation, tools, and infrastructure. Naoum, Fong, and Walker [41] emphasize the need for the appointment of an investment project manager, competencies of the project manager, high authority of the project manager, clearly defined project objectives, establishment of the project team, and support of the company's management for the project. Pan et al. [51] indicate cost efficiency, time schedules, quality of works, health and safety issues, sustainability into construction project management practices, public procurement and legal, and statutory acceptance. Hwang et al. [52] found that "construction management", "coordination between different parties", and "availability of workers on site" were the three most important factors influencing 
the construction project schedules in Singapore. Panibratov and Larionov [53] studied construction companies in Russia and identified a whole range of different CSFs, namely complications in the formation of market relations, disparately oriented economic interests of construction market participants, insufficient reliability of many construction organizations, financial insolvency of clients, and lack of adequate funding. Gudienè et al. [10] showed that with regards to construction projects in Lithuania, the highest rated CSFs are (1) clear and realistic project objectives, (2) project planning, (3) competencies of the project manager, (4) relevant past experience of the project manager/team, (5) competencies of the project manager/team, (6) client's clear and precise goals (7) project value, (8) project complexity and uniqueness, (9) experience of the project manager, and (10) client's ability to make timely decisions.

Ulubeyli et al. [54] point to the quality of completed facilities, capability to meet clients' expectations related to quality, safety of the complex, architectural design, and quality of final products. Jaafar et al. [55] focus on planning, business strategy, marketing, project management, financial management, networking, management capabilities, and the use of intangible assets. Kavishe et al. [56] bring up the importance of public-private partnership (PPP), sustainability assessment from the feasibility phase, and durability of construction works. Muhammad and Johar [38] also indicate the importance of PPP, context specificity of various administrative conditions, legal-administrative and environmental issues, equitable risk allocation, stable political system, reputable developer, action against errant developer, and consistent monitoring. Banihashemi et al. [57] propose a whole host of CSFs for integration of sustainability into construction project management practices.

Sobieraj and Metelski [22] point to the activity of companies in the market environment (e.g., experienced project manager, risk evaluation, time schedule and detailed specification of the various stages of investment project implementation, professional business plan with projections of costs, profits and financial cash flows, flexible, well-developed implementation plan, good register of documents, etc.), highly advanced technologies and the use of appropriate market relations, and a few external factors, e.g., stable political system, stability of economic and tax systems, stability and transparency of the legal system and well-targeted environmental policies. In addition, Odeyinka and Yusif $[48,53]$ distinguish such variables as well-functioning cooperation with stakeholders, which allows the proper formation of market relations and enables the convergence of the economic interests of all participants in the construction market [53], and the linkage of the company to the financial sector (to avoid defaulting on financial obligations), as well as the proper preparation of the workforce (i.e., knowledge and competence of employees, level of education, professional experience, completed courses, linkage of the company with academic centers, etc.). Moreover, construction project failures are often determined by financial insolvency of clients, and the lack of adequate financing $[22,48,53]$.

According to the Project Management Institute and other researchers, the following factors have the greatest impact on project success: competent project managers with necessary skills and authority, clearly defined and widely understood project objectives, competent and experienced project teams, and top management support [5]. Moreover, top management support is related to goal setting. Construction project managers need to be organized, knowledgeable and able to multitask. They must also have some essential skills, such as communication, and planning and the ability to delegate tasks to other workers. Related to this is the need for listing investment processes with necessary resources, developing a plan with responsibilities and deliverables, defining project scope and risks, and then monitoring changes as they occur [5,22]. Sobieraj [5] attributes great importance for success to the investment project initiation phase, during which emphasis should be placed on the full articulation of goals and objectives, and key tasks for the project team.

All that is set out above relates to the success of investment projects and demonstrates that there is a wide range of factors that stay behind successful completion of investment projects, and, as highlighted by Sobieraj and Metelski [22], even construction professionals themselves struggle to reach some sort of consensus in this regard. This study provides a 
very thorough review of the literature and narrows down the list of the most commonly typified construction project success factors to only 28 , incorporating only those that are most frequently repeated and cited in the literature by at least a few authors, as well as those that are relevant when viewed in the context of investment projects carried out in Poland. The variables used in the study are indicated and described in Table 1. A more detailed justification of the relevance of the Polish context is presented in Appendix A Table A2. The data comprise 197 observations for 28 selected variables.

This paper is centered on a survey conducted among construction experts from Poland so as to get to know their subjective perspectives about critical success factors affecting investment project implementation by construction companies in Poland. The study employs Bayesian model averaging (BMA) to identify and evaluate critical success factors of construction projects. The subsequent section is dedicated to a more detailed description of the research method used to analyze the survey data.

Table 1. List of variables used in the analysis.

\begin{tabular}{|c|c|c|}
\hline Variable & Name of Variable & Cited by Authors \\
\hline$X_{1}$ & $\begin{array}{l}\text { Key competences and high authority of the } \\
\text { project manager }\end{array}$ & $\begin{array}{l}\text { Sobieraj [5]; Gudienè et al. [10]; Sayles and Chandler [23]; Naoum, } \\
\text { Fong, and Walker [41]; Baker, Murphy, and Fisher [45]; Locke [46]; } \\
\text { The Standish Group [49,50]; Huemann et al. [58]; } \\
\text { Dziekoński [59,60]; Grzesik and Piwowar-Sulej [61]; Podgórska } \\
\text { and Pichlak [62] }\end{array}$ \\
\hline$X_{2}$ & $\begin{array}{l}\text { Timely project planning and reviews } \\
\text { (organizing cyclical meetings to assess } \\
\text { project progress) }\end{array}$ & $\begin{array}{l}\text { Sobieraj [5]; Gudienè et al. [10]; Sobieraj and Metelski [22]; Sayles } \\
\text { and Chandler [23]; Pinto [42]; Martin [43]; Cleland and King [44]; } \\
\text { Baker, Murphy, and Fisher [45]; Locke [46]; The Standish } \\
\text { Group [49,50]; Jaafar et al. [55]; Dziekoński [60]; Kapliński [63]; } \\
\text { Dziadosz and Rejment [64] }\end{array}$ \\
\hline$X_{3}$ & $\begin{array}{l}\text { Selection of an adequate and competent } \\
\text { project team with relevant past experience } \\
\text { (commitment of project teams in reaching } \\
\text { project objectives) }\end{array}$ & $\begin{array}{l}\text { Gudienè et al. [10]; Sobieraj, Metelski, and } \\
\text { Nowak [37]; Naoum, Fong, and Walker [41]; Martin [43]; Baker, } \\
\text { Murphy, and Fisher [45]; Grzesik and Piwowar-Sulej [61] }\end{array}$ \\
\hline$X_{4}$ & $\begin{array}{l}\text { Adequate communication and provision of } \\
\text { information, information channels } \\
\text { (dissemination of information about project } \\
\text { implementation) }\end{array}$ & $\begin{array}{l}\text { Sayles and Chandler [23]; Pinto [42]; Martin [43]; Cleland and } \\
\text { King [44]; Baker, Murphy, and Fisher [45]; Locke [46]; } \\
\text { Gohar et al. [65]; Chan et al. [66]; Kania, Radziszewska-Zielina, } \\
\text { and Śladowski [67] }\end{array}$ \\
\hline$X_{5}$ & Control and accountability systems & $\begin{array}{l}\text { Sayles and Chandler [23]; Martin [43]; Baker, Murphy, and } \\
\text { Fisher [45]; Locke [46]; Kapliński et al. [68] }\end{array}$ \\
\hline$X_{6}$ & $\begin{array}{l}\text { Consistent monitoring at many levels (e.g., } \\
\text { country's economic situation on an ongoing } \\
\text { basis, monitoring of the environment, } \\
\text { monitoring of the emergence of new building } \\
\text { technologies, etc.), and market research }\end{array}$ & $\begin{array}{l}\text { Sobieraj and Metelski [22]; Sayles and Chandler [23]; Muhammad } \\
\text { and Johar [38]; Pinto [42]; Cleland and King [44]; Baker, Murphy, } \\
\text { and Fisher [45] }\end{array}$ \\
\hline$X_{7}$ & $\begin{array}{l}\text { Accurate defining and communicating } \\
\text { project goals and objectives (task } \\
\text { orientation/management by objectives) }\end{array}$ & $\begin{array}{l}\text { Gudiene et al. [10]; Sobieraj and Metelski [22]; Naoum, Fong, and } \\
\text { Walker [41]; Martin [43]; Baker, Murphy, and Fisher [45]; The } \\
\text { Standish Group [49,50]; Gohar et al. [65] }\end{array}$ \\
\hline$X_{8}$ & External factors & $\begin{array}{l}\text { Gudienè et al. [10]; Sobieraj and Metelski [22]; Pasławski and } \\
\text { Jastrząb [69]; Połoński [70]; Leśniak [71,72]; Leśniak and } \\
\text { Plebankiewicz [73] }\end{array}$ \\
\hline$X_{9}$ & Provision of sufficient resources & $\begin{array}{l}\text { Sobieraj [5]; Martin [43]; The Standish Group [49,50]; } \\
\text { Pan et al. [51] }\end{array}$ \\
\hline$X_{10}$ & Top-level (senior) management support & $\begin{array}{l}\text { Sobieraj [5]; Sobieraj and Metelski [22]; Aksorn et al. [27]; Al } \\
\text { Haadir and Panuwatwanich [28]; Sobieraj, Metelski, and } \\
\text { Nowak [37]; Naoum, Fong, and Walker [41]; Pinto [42]; } \\
\text { Martin [43]; Cleland and King [44]; The Standish Group [49,50] }\end{array}$ \\
\hline$X_{11}$ & $\begin{array}{l}\text { Logistical requirements and support of the } \\
\text { construction backup facilities }\end{array}$ & $\begin{array}{l}\text { Cleland and King [44]; The Standish Group [49,50]; } \\
\text { Kapliński et al. [68]; Sobotka and Czarnigowska [74] }\end{array}$ \\
\hline
\end{tabular}


Table 1. Cont.

\begin{tabular}{|c|c|c|}
\hline Variable & Name of Variable & Cited by Authors \\
\hline$X_{12}$ & $\begin{array}{l}\text { Project time schedules and detailed project } \\
\text { description and specification of the various } \\
\text { stages of project implementation and any } \\
\text { predictable events between its stages }\end{array}$ & $\begin{array}{l}\text { Sobieraj [5]; Sobieraj and Metelski [22]; Pinto [42]; Cleland and } \\
\text { King [44]; Pan et al. [51]; Leśniak and Plebankiewicz [73]; Sobieraj, } \\
\text { Metelski, and Nowak [75]; Jaśkowski and Biruk [76] }\end{array}$ \\
\hline$X_{13}$ & Executive development and staff training & $\begin{array}{l}\text { Sobieraj [5]; Sobieraj and Metelski [22]; Sobieraj, Metelski, and } \\
\text { Nowak [37]; Pinto [42]; Cleland and King [44] }\end{array}$ \\
\hline$X_{14}$ & $\begin{array}{l}\text { Manpower and organization (project } \\
\text { management, construction management, } \\
\text { networking, management capabilities, } \\
\text { coordination between different parties, and } \\
\text { availability of workers on site) }\end{array}$ & $\begin{array}{l}\text { Sobieraj [5]; Sobieraj, Metelski, and Nowak [37]; Pinto [42]; } \\
\text { Cleland and King [44]; Hwang et al. [52]; Jaafar et al. [55]; } \\
\text { Sobieraj and Metelski [77] }\end{array}$ \\
\hline$X_{15}$ & $\begin{array}{l}\text { Importance financial support, sufficient } \\
\text { project funding and financial management }\end{array}$ & $\begin{array}{l}\text { Sobieraj [8]; Baker, Murphy, and Fisher [45]; Panibratov and } \\
\text { Larionov [53]; Jaafar et al. [55]; Kapliński et al. [68]; Sobieraj and } \\
\text { Metelski [77] }\end{array}$ \\
\hline$X_{16}$ & $\begin{array}{l}\text { Accurate estimation of project costs } \\
\text { (cost-efficiency) }\end{array}$ & $\begin{array}{l}\text { Baker, Murphy and Fisher [45]; Pan et al. [51]; Kapliński [63]; } \\
\text { Leśniak and Zima [78] }\end{array}$ \\
\hline$X_{17}$ & $\begin{array}{l}\text { Minimization of difficulties encountered in } \\
\text { the initial phase of the project }\end{array}$ & $\begin{array}{l}\text { Sobieraj [5]; Baker, Murphy, and Fisher [45]; Kulejewski [79]; } \\
\text { Sobieraj [80] }\end{array}$ \\
\hline$X_{18}$ & Established PM procedures & $\begin{array}{l}\text { Sobieraj and Metelski [5]; Sobieraj, Metelski and Nowak [37]; } \\
\text { Baker, Murphy, and Fisher [45]; Locke [46]; Hsino and } \\
\text { Pasławski [81] }\end{array}$ \\
\hline$X_{19}$ & $\begin{array}{l}\text { Project strategy that combines individual and } \\
\text { group skills to achieve the best balance of } \\
\text { resources available at the right time }\end{array}$ & $\begin{array}{l}\text { Pinto [42]; Martin [43]; Sullivan and Harris [47]; Jaafar et al. [55]; } \\
\text { Tracz [82] }\end{array}$ \\
\hline$X_{20}$ & $\begin{array}{l}\text { Clients (end-users) engaged in the project } \\
\text { management activities at an executive level, } \\
\text { as they are the ones who have a view of the } \\
\text { project in its holistic context }\end{array}$ & $\begin{array}{l}\text { Gudiene et al. [10]; Sayles and Chandler [23]; Pinto [42]; Sullivan } \\
\text { and Harris [47]; The Standish Group [49,50]; Sobieraj [80] }\end{array}$ \\
\hline$X_{21}$ & $\begin{array}{l}\text { Importance of public-private } \\
\text { partnerships (PPPs) }\end{array}$ & $\begin{array}{l}\text { Sobieraj [5]; Muhammad and Johar [38]; Kavishe et al. [56]; } \\
\text { Siemiatycki [83]; Sobieraj [84]; Węrgyn [85,86] }\end{array}$ \\
\hline$X_{22}$ & Equitable risk allocation (risk) & $\begin{array}{l}\text { Sobieraj and Metelski [22]; Górski and Dziadosz [24]; Muhammad } \\
\text { and Johar [38]; Kavishe et al. [56]; Dziadosz and Rejment [64]; } \\
\text { Gohar et al. [65]; Kapliński [68]; Skorupka [87]; Bizon-Górecka } \\
\text { and Górecki [88]; Turskis et al. [89]; Szymański [90]; Bryx [91] }\end{array}$ \\
\hline$X_{23}$ & $\begin{array}{l}\text { Legal-administrative and environmental } \\
\text { issues, bureaucracy }\end{array}$ & $\begin{array}{l}\text { Sobieraj [8]; Muhammad and Johar [38]; Baker, Murphy, and } \\
\text { Fisher [45]; Sobieraj, Metelski, and Nowak [75]; Sobieraj and } \\
\text { Metelski [77]; Grzywiński [92] }\end{array}$ \\
\hline$X_{24}$ & $\begin{array}{l}\text { Integration of sustainability into construction } \\
\text { project management practices }\end{array}$ & $\begin{array}{l}\text { Pan et al. [51]; Kavishe et al. [56]; Banihashemi et al. [57]; Górecki } \\
\text { and Diaz-Madronero [93]; Michalak and Michałowski [94] }\end{array}$ \\
\hline$X_{25}$ & Health and safety issues & Górny [6]; Pan et al. [51]; Ulubeyli et al. [54] \\
\hline$X_{26}$ & Project value (quality) and uniqueness & Sobieraj [5]; Gudienè et al. [10]; Pan et al. [51]; Ulubeyli et al. [54] \\
\hline$X_{27}$ & $\begin{array}{l}\text { Complications in the formation of } \\
\text { market relations }\end{array}$ & $\begin{array}{l}\text { Sobieraj [5]; Sobieraj and Metelski [22]; Panibratov } \\
\text { and Larionov [53] }\end{array}$ \\
\hline$X_{28}$ & Highly technological advancement & $\begin{array}{l}\text { Sobieraj and Metelski [22]; Ghoddousi and Hosseini [33]; } \\
\text { Kapliński et al. [68] }\end{array}$ \\
\hline
\end{tabular}




\section{Materials and Methods}

\subsection{Data Collecting: Questionnaire and Variables}

The objective of this study is to explore the knowledge of successful project management in the area of construction sector in Poland. The study consists of a general questionnaire survey with a list of relevant questions addressing 28 variables, and a few metric questions, i.e., the number of years in business, number of investment projects completed in the last 5 years, number of employees, location, etc. The questionnaire questions fathom the opinions of construction managers on key factors influencing the implementation of investment-construction projects in Poland. The survey was conducted on a sample of 197 respondents, comprising managers and directors of construction companies from the Polish construction industry. The structure of the research sample was made up of respondents that were selected in view of the number of completed investment projects in the construction sector. The survey was held at the Forum of Construction Managers. More specifically, the survey was conducted among companies that are members of such organizations as Polish Association of Construction Industry Employers (PZPB), Polish Association of Construction Managers (PSMB), and Polish Association of Developers (PZFD). According to CSO data, the potential population of construction companies in Poland oscillates around 774,000 [1]. The members of PZPB, PSMB, and PZFD are 101, 69, and 221 companies, respectively. Some of these companies are members in two or all three of the above organizations. In case of a single company, the questionnaire may have been filled in by the managerial staff consisting of more than 10 people-especially in those large companies, such as Dom Development, Robyg, Warbud, Unibep, Strabag, Skanska, etc.

In order for the survey to provide reliable conclusions, it was necessary to select an appropriate number of respondents. The minimum sample size is determined by the sample design and depends on several factors, such as the size of the population (1), expected proportion of the phenomenon under study in the population (2), confidence level (3), and standard error of estimate (4). Therefore, since the survey is about the opinion of companies' managers from the construction sector, it is necessary to know the number of construction companies in the entire country. Regarding the representation of the phenomenon under study in the total population of Polish companies, given that the survey deals with a variety of issues in the construction industry and, in particular, with opinions in this regard among construction managers, the expected proportion of the surveyed questions was assumed to be at the level of $50 \%$. Note that, in statistics, the frequency of an event $i$ is the number $n_{i}$ of times the observation occurred/recorded in an experiment or study. Given the context of the opinionated topics in relation to the entire potential population of construction companies in Poland, the study does not assume precise expectations regarding the relative frequency of occurrence of the analyzed problems in the surveyed sample. With no such knowledge, the level of 50\% was considered as the most accurate.

As for the confidence level (i.e., which shows how confident one can be about the results and whether they are applicable to the population as a whole), the study uses a default assumption of $95 \%$ (hence $\alpha=0.05$ ). With respect to the standard error of the estimate, it is equal to $7 \%$, which means that the obtained survey results may deviate from the actual values in the population by $7 \%$. With all the above data, it is possible to see how many respondents should take part in the survey. A specific formula is used for this purpose (minimum sample size):

$$
n=\frac{P(1-P)}{\frac{e^{2}}{Z^{2}}+\frac{P(1-P)}{N}}=196
$$

where we have the following:

$P$-expected proportion of the phenomenon under study in the population;

$e$-standard error of estimate; 
$Z$ - the value calculated on the basis of the adopted confidence level (which is 95\%; therefore, $Z=1.96$ ). The confidence coefficient is the confidence level stated as a proportion, rather than as a percentage;

$N$-the size of the population.

The survey was targeted at a larger number of companies, but ultimately it was possible to collect complete responses from 197 companies. The standard error $=\sqrt{p x q / n}$ $=\sqrt{50 \times 50 / 192}=3.6$.

More specifically, there are 28 questions (variables) that are considered relevant to this particular type of analysis. The questionnaire questions were of a single-choice, closedended nature, and all answers were based on a 7-point Likert scale: (1) I strongly disagree, (2) I do not agree, (3) I rather disagree, (4) it is difficult to say, (5) I rather agree, (6) I agree, and (7) I definitely agree. This scale was used to capture the importance, or weights, of the critical success factors for construction projects in Poland. Seven-point Likert items have been shown to be more accurate, easier to use, and a better reflection of a respondent's true evaluation. In light of all these advantages, even when compared to higher-order items, 7-point items appear to be the best solution for questionnaires such as those used in usability evaluations.

\subsection{Variables and Selection and Characteristics of the Study Sample}

The whole study was performed according to a specific schedule, which divided the research activities into the following stages. The first stage consisted of the elaboration of methodological assumptions, based on the subject literature and numerous interviews with people from the industry. In this stage, we formulated and specified the objectives. The second stage involved the development and implementation of the questionnaire. It comprised the formulation and selection of appropriate questionnaire questions, so that they were adjusted to the respondents' level of knowledge. All of the survey questions with associated numbers of responses in each category of the seven-point Likert-scale can be found in Appendix A Table A1. Stage three concerned the elaboration and verification of the collected research material, consisting of quantitative and qualitative data analysis. The study sample consisted of the respondents (i.e., construction professionals and experts with knowledge and experience in project management) from micro, small, medium, and large companies from all over Poland. They were asked to rate the proposed success factors.

\subsection{Research Method}

There is a whole host of different survey analysis methods. One of them is, for example, regression analysis. Other examples include Structural Equations Modeling (SEM), ANOVA Test, Conjoint Analysis, T-Test, Crosstab Analysis, Exploratory Factor Analysis (EFA), and Confirmatory Factor Analysis (CFA), to name only a few. This study employs OLS regression analysis which estimates the relationships between the dependent variable (successful project completion) with 28 independent variables (the CSFs indicated in the literature review section). OLS regression analysis provides the best fit for the analysis of CSFs, since it sorts out which of the CSFs have the greatest impact on the phenomenon under study. The preferred approach is BMA, since it addresses the uncertainty that arises at the model selection stage. More specifically, the BMA approach allows for the analysis of the entire set of all possible models and optimization in this regard, resulting in the estimation of the most relevant model parameters (i.e., regression coefficients). It is a useful method when trying to determine the impact of an exogenous variable on the problem under study.

To determine the relative ranking of the critical success factors, the scores are subsequently subjected to Bayesian model averaging (BMA) analysis, which uses Bayesian inference to solve the problems of appropriate model selection, and combined estimation and prediction, thereby addressing simple model selection criteria and obtaining less risky predictions [95]. This method produces posterior inclusion probabilities (PIPs) for all combinations of predictors. By averaging the parameter estimates of all possible 
model combinations, and weighting each of these estimates with its corresponding model probability, the sought-after (most accurate) parameter estimate of the most appropriate model was obtained. In other words, model averaging consists of using several models simultaneously to make predictions and infer optimal model parameters [96].

To conduct the empirical study the same methodological approach was used as described in Fragoso et al. [95] and Banner and Higgs [96]. The endogenous variable is a subjective evaluation of the perceived success of investment projects by those taking part in the survey, taking into account the 7-point Likert scale. Furthermore, respondents were asked to consider such aspects of investment project success as timeliness of completion of entire construction projects and their individual stages (time component), occurrence of budget overruns, access to finance and all related issues (financial component), timeliness of commissioning of individual stages of investment projects, and client satisfaction (quality component).

The model employs the Bayesian model sampling (BMS) function described by Zeugner and Feldkircher [97], which implements Bayesian model averaging for linear regression models. It is worth mentioning that BMS allows for different prior structures, including binomial-beta prior and the "hyper- $g$ " specification for Zellner's $g$-prior. It also allows researchers to specify their own model priors, setting the prior inclusion probabilities at one's discretion.

BMA has an advantage over other econometric techniques in that it consistently and systematically, and more readily deals with model uncertainty [98]. This method uses Bayesian inference to select the right model and solves the problem of combined estimation and forecasting. The BMA adopts a relatively simple criterion for model selection, although the use of this methodology is not necessarily straightforward, and the choice of the final model based on the BMA often depends on various aspects and the resulting assumptions and situational choices. The Bayesian model averaging allows us to solve the problem of uncertainty associated with determining the appropriate choice of model specification. The problem arises when there are too many potential exogenous explanatory regressors. In other words, BMA is a method that indicates which explanatory variables should be included in a canonical linear regression model, when there is a choice of many alternative models and potential variables contained in a matrix $X$ :

$$
y=\alpha_{\gamma}+X_{\gamma} \beta_{\gamma}+\varepsilon, \varepsilon \sim N\left(0, \sigma^{2} I\right),
$$

where $y$ is the dependent variable (i.e., successful project completion), $\alpha_{\gamma}$ is a constant, $\beta_{\gamma}$ are the coefficients, and $\varepsilon$ is a normal IID error term with variance $\sigma^{2}$.

When it comes to the number of potential choices, there are as many as $X_{\gamma} \in\{X\}$ variables that a researcher can choose from. Suppose that matrix $X$ contains $K$ potential explanatory variables. This means that there are $2^{K}$ potential sets of explanatory variables and, thus, also $2^{K}$ models. The choice with regards to specifications may have a significant impact on the estimated values of parameters for individual variables. On the basis of a single specification of a linear regression model encompassing all variables, the inference cannot be very reliable, and with a small number of observations, it is ineffective or even impracticable. The BMA approach solves this problem, since it takes into account all possible combinations of $\{X\}$ and establishes a weighted average for all of them. The model weights considered in the averaging method are determined based on posterior probabilities, which can be described with the Bayes theorem [97]:

$$
p\left(M_{\gamma} \mid y, X\right)=\frac{p\left(y \mid M_{\gamma}, X\right) p\left(M_{\gamma}\right)}{p(y \mid X)}=\frac{p\left(y \mid M_{\gamma}, X\right) p\left(M_{\gamma}\right)}{\sum_{s=1}^{2^{K}} p\left(y \mid M_{s}, X\right) p\left(M_{s}\right)}
$$

where $p(y \mid X)$ is the probability that is constant for all models and therefore can be perceived as a multiplier term. In turn, $p\left(M_{\gamma} \mid y, X\right)$ is the Posterior Model Probability (denoted as PMP), which is proportional to the marginal probability $p\left(y \mid M_{\gamma}, X\right)$ (the probability 
resulting from the model $M_{\gamma}$ ) multiplied by $p\left(M_{\gamma}\right)$, i.e., the prior model probability. The latter indicates the assumptions made by the researcher about the model $M_{\gamma}$ based on his/her subjective preferences. The procedure of renormalization subsequently yields certain posterior model probabilities and model-weighted posterior distributions for every $\beta$ coefficient. It can be expressed with the following formula:

$$
p(\theta \mid y, X)=\sum_{\gamma=1}^{2^{K}} p\left(\theta \mid M_{\gamma}, y, X\right) \frac{p\left(M_{\gamma} \mid X, y\right) p\left(M_{\gamma}\right)}{\sum_{s=1}^{2^{K}} p\left(M_{s} \mid y, X\right) p\left(M_{s}\right)}
$$

As a general rule, before estimating BMA parameters, it is necessary to make certain assumptions about the model priors $p\left(M_{\gamma}\right)$. In case when there is lack of adequate knowledge about specific model parameters, the most common assumption, is to assume the uniform probability of these distributions. The adoption of a specific estimation framework has an impact on the obtained results, i.e., posterior distributions, which are also known as posteriors $p\left(\theta \mid M_{\gamma}, y, X\right)$. The study relies on a linear Bayesian regression model with the $g$-prior developed by Zellner [99]. The Zellner's $g$ is an objective prior for the coefficients of a multiple regression. The posterior distribution of the coefficients follows a $t$-distribution with expected value $E\left(\beta_{\gamma} \mid y, X, g, M_{\gamma}=\frac{g}{1+g} \hat{\beta}_{\gamma}\right)$, with Zellner's $g$ and $\hat{\beta}_{\gamma}$ denoting the standard OLS estimator. In essence, the empirical part of the study is based on the model described by Equation (2); certain assumptions are therefore made, i.e., constant $\alpha_{\gamma}$, error variance $\sigma^{2}$, error distribution described $\varepsilon \sim N\left(0, \sigma^{2} I\right)$, priors that are evenly distributed in their domains, i.e., $p\left(\alpha_{\gamma}\right) \propto 1$ and $p(\sigma) \propto \sigma^{-1}$, respectively. Note that the assumed prior for the errors' standard deviations $(\sigma)$ is not uniform. This prior is uniform for $\ln (\sigma)$. Moreover, from this assumption, we can obtain the prior for $\sigma$ in the assumed form (i.e., proportional to $1 / \sigma)$. Such prior follows Jeffrey's rule, and it is often called Jaffrey's prior). However, it is not known exactly what these distributions are, and therefore their priors are improper (they integrate to infinity, and they are $\sigma$-finite measures).

Similarly, there are certain assumptions made about the regression coefficients. It was assumed that they can be described by a normal distribution with zero mean and a variance, which follows the Zellner's $g$-prior given by the following: $g \sigma^{2}\left(X_{\gamma}^{T} X_{\gamma}\right)^{-1}, \beta_{\gamma} \mid g \sim$ $N\left(0, g \sigma^{2}\left(X_{\gamma}^{T} X_{\gamma}\right)^{-1}\right)$. In the case of the regression coefficients, assuming that their mean is zero reflects the lack of knowledge about their sign, while the variance and covariance address the structure of the data $X_{\gamma}$. In turn, when it comes to the researcher's belief about the parameters, it is reflected by the priors' dispersion. The expected value of the coefficients is a convex combination of the zero mean and the OLS estimator. The size of the $g$-priors reflects the researcher's belief about the coefficients themselves. As $g$ increases, so does the variance of the coefficients, which in turn reflects a drop of the researcher's confidence on the assumptions about the aforementioned mean (which is assumed to be zero, due to the lack of an a priori knowledge about the coefficients). In general, the more conservative the values of $g$ used in the assumptions, the greater the importance of the priors; for smaller values of $g$, it is more likely that the expected value of the coefficients will converge to the zero mean of the prior. When $g$-prior increases, the coefficient estimator approaches the OLS estimator. Thus, taking a specific $g$-prior assumption affects the posterior variance $\beta_{\gamma}$ of the coefficients: $\operatorname{COV}\left(\beta_{\gamma} \mid y, X, g, M_{\gamma}\right)=\frac{(y-\bar{y})^{T}(y-\bar{y})}{N-3} \frac{g}{1+g}\left(1-\frac{g}{1+g} R_{\gamma}^{2}\right)\left(X_{\gamma}^{T} X_{\gamma}\right)^{-1}$. Moreover, the posterior covariance differs from the covariance of the OLS estimator in that it takes into account the $g$-prior. In turn, the marginal likelihood $p\left(y \mid M_{\gamma}, y, X\right)$, resulting from the prior framework, depends on the model size $k_{\gamma}$, which can be expressed in the following way: $p\left(y \mid M_{\gamma}, X, g\right) \propto(y-\bar{y})^{T}(y-\bar{y})^{-\frac{N-1}{2}}(1+g)^{-\frac{k \gamma}{2}}\left(1-\frac{g}{1+g}\right)^{-\frac{N-1}{2}}$. 


\section{Results}

The successful project completion is modeled with the use of linear OLS regression as follows:

$$
y_{i}=\beta_{0}+\beta_{m}^{T} X_{i}^{m}+u_{i}
$$

where $X_{i}^{m}-k_{m}$ is a dimensional vector that expresses explanatory variables (or CSFs) which explain the successful project completion, the dependent variable; $\beta_{m}^{T}$ is the vector that reflects marginal contributions of the explanatory variables; $\beta_{0}$ is the intercept of the regression; and $u_{i}$ is the error term.

The study aims to investigate the relationship of multiple exogenous variables (i.e., preselected CSFs) on the endogenous variable, which is successful project completion. Therefore, in this case, a regression analysis provides the best fit for the conducted analysis.

Table 2 shows the respective results. The posterior inclusion probabilities (PIPs) express the probabilities that a specific regressor forms part of the "true" linear regression model. The PIPs represent the sum of the PMPs for all models in which a specific variable was included, and thus the capture the importance of the regressors in explaining the survey data. If PIP is $100 \%$ for a given variable, as is the case for the planning and reviews and competent project manager, it means that virtually all of the posterior model mass rests on these specific regressors. Table 2 also contains the posterior means (Post. Mean) and posterior standard deviations (Post. St. Dev.). The former shows the extent of the effect of a given determinant (Post. Mean shows the coefficients averaged across all models, including the ones wherein the variable was not contained, implying that the coefficient is zero in such case.), whereas the latter assesses its deviation. It is important to remember that typically the responses show certain heterogeneity, meaning that a small number of complementary determinants may contribute to the scope of successful project completion. On the other hand, some of the CSFs determinants may turn out to be substitutes insofar as their interpretation is concerned. This means that there is some probability of an early inclusion of a specific regressor/determinant.

When viewed through the lens of the PIP value, Table 2 indicates a certain prioritization of the preselected factors determining investment project success. As it was mentioned earlier, the results indicate with 100\% certainty that all posterior model mass rests on the models that include two variables, namely planning and reviews and competent project manager. Other CSFs have corresponding PIP values within the range of 4.56-89.83\%. These results can be interpreted in that the higher the PIP, the more reliable a given CSF is in terms of its association with the endogenous variable, and thus it can be ranked higher among all CSFs.

The coefficient sign can also be inferred from the fifth column of Table 2, "Cond. Pos. Sign", which stands for the "posterior probability of a positive coefficient expected value conditional on inclusion" [97]. Finally, the last column of Table 2, "Idx", denotes the index of the variables' appearance in the dataset, which might be useful when sorting the results by PIP values.

When it comes to evaluating construction projects, the problem is that each of them is in its own way unique and at the same time also very complex, so there are many factors that determine the extent to which they can be successfully managed. On the other hand, the common practice in empirical research is based on selecting a single model from an infinite space of all possible models. It must be remembered, however, that when dealing with OLS regression, there are actually as many as $2^{K}$ possible regressor combinations, the theoretical value of the common prior model probability is equal to $p\left(M_{\gamma}\right)=2^{-K}$, and the expected model size is $\sum_{k=0}^{K}\left(\begin{array}{c}K \\ k\end{array}\right) k 2^{-K}=K / 2$. Therefore, by choosing one particular model it is virtually a given that it will be flawed to some extent and will not fully describe reality. Insofar as the OLS regression model is concerned the most common problems are low goodness of fit of the model, heteroskedasticity and multicollinearity. However, there is still uncertainty surrounding the selection of variables for such model (of which there are 
usually only a few taken into account so as not to violate the multicollinearity assumption) and the reliability of its coefficient parameter estimates.

Table 2. Coefficient results (BMA).

\begin{tabular}{|c|c|c|c|c|c|}
\hline Variable Name & PIP & Post. Mean & Post. St. Dev. & Cond. Pos. Sign & Idx \\
\hline Planning and Reviews & 1.0000 & 0.1614 & 0.0333 & 1.0000 & 3 \\
\hline Competent Project Manager & 1.0000 & 0.2590 & 0.0444 & 1.0000 & 28 \\
\hline Information and Communication Channels & 0.8983 & 0.1688 & 0.0801 & 1.0000 & 5 \\
\hline Project Value and Uniqueness & 0.8603 & 0.1101 & 0.0587 & 1.0000 & 9 \\
\hline Client Engagement & 0.8516 & 0.1091 & 0.0604 & 1.0000 & 22 \\
\hline Market Relations & 0.8110 & 0.1004 & 0.0620 & 1.0000 & 25 \\
\hline Established PM Procedures & 0.5920 & 0.0570 & 0.0559 & 1.0000 & 21 \\
\hline Experienced Project Team & 0.5433 & 0.0661 & 0.0711 & 1.0000 & 13 \\
\hline Importance of Financial Support & 0.4890 & 0.0437 & 0.0544 & 1.0000 & 19 \\
\hline Consistent Monitoring & 0.4600 & 0.0480 & 0.0616 & 1.0000 & 27 \\
\hline Senior Management Support & 0.3326 & 0.0206 & 0.0345 & 1.0000 & 18 \\
\hline Project Objectives & 0.3030 & 0.0217 & 0.0392 & 1.0000 & 1 \\
\hline Manpower and Organization & 0.2690 & 0.0181 & 0.0353 & 1.0000 & 17 \\
\hline Project Time Schedules & 0.2603 & 0.0172 & 0.0348 & 1.0000 & 26 \\
\hline Equitable Risk Allocation & 0.2556 & 0.0142 & 0.0320 & 1.0000 & 11 \\
\hline Minimization of Initial Phase Difficulties & 0.2443 & 0.0158 & 0.0360 & 1.0000 & 15 \\
\hline Control and Accountability Systems & 0.2430 & 0.0198 & 0.0421 & 1.0000 & 7 \\
\hline Executive Development and Staff Training & 0.2183 & 0.0129 & 0.0305 & 1.0000 & 20 \\
\hline Provision of Sufficient Resources & 0.2173 & 0.0139 & 0.0325 & 1.0000 & 4 \\
\hline Project Strategy, Mission, and Philosophy & 0.2140 & 0.0120 & 0.0305 & 0.9735 & 23 \\
\hline Estimation of Project Costs & 0.2080 & 0.0124 & 0.0304 & 1.0000 & 12 \\
\hline $\begin{array}{c}\text { Administrative, Environmental, and } \\
\text { Bureaucratic Issues }\end{array}$ & 0.2053 & 0.0156 & 0.0367 & 1.0000 & 6 \\
\hline Highly Technological Advancement & 0.2023 & 0.0125 & 0.0321 & 1.0000 & 10 \\
\hline Health and Safety Issues & 0.1043 & 0.0042 & 0.0194 & 0.9936 & 2 \\
\hline Logistical Requirements and Support & 0.0963 & 0.0046 & 0.0176 & 1.0000 & 24 \\
\hline Integration of Sustainability & 0.0933 & 0.0011 & 0.0122 & 0.8642 & 16 \\
\hline External Factors & 0.0676 & 0.0025 & 0.0146 & 1.0000 & 8 \\
\hline Public-Private Partnerships & 0.0456 & 0.0003 & 0.0093 & 0.7445 & 14 \\
\hline
\end{tabular}

Source: authors' own calculations.

Generally, considering the PIP values, the variables explaining Successful Project Completion can be divided into three groups. Distinguishing the regressors by relevance of provided evidence makes it easier to assess their reliability in explaining variability of endogenous variable. Those with the highest PIP value provide the strongest evidence, justifying their inclusion in the true regression model describing the variability of the response variable (successful project completion). The division of regressors is based on the PIP range they fall into, which determines the strength of the evidence provided:

- The first group are regressors with strong evidence for which PIP $>0.5$. This group includes variables that exhibit greater posterior inclusion probability compared to the priors. In the case of these variables, it can be concluded that there is a strong evidence justifying their inclusion in the true model. The study indicates eight such variables which belong to the group of regressors providing the strongest evidence in explaining the variability of successful project completion, namely planning and reviews, competent project manager, information and communication channels, project value and uniqueness, client engagement, market relations, established PM procedures, and experienced project team.

- The second group comprises regressors with medium evidence, where $0.5 \geq P I P>0.2$. There are 15 such determinants in the case of the CSF analysis, namely importance of financial support; consistent monitoring; senior management support; project objectives; manpower and organization; project time schedules; equitable risk allocation; minimization of initial phase difficulties; control and accountability systems; executive 
development and staff training; provision of sufficient resources; project strategy, mission, and philosophy; estimation of project costs; administrative, environmental, and bureaucratic issues; and highly technological advancement.

- The third group is composed of regressors with weak evidence $(P I P \leq 0.2)$, i.e., those with a relatively low probability of posterior inclusion compared to priors, although it can still be shown that they also explain the variability of the response variable to some extent. Regressors belonging to this group provide the weakest evidence that they are in fact true determinants of the endogenous variable under investigation. There are five such regressors/determinants, i.e., health and safety issues, logistical requirements and support, integration of sustainability, external factors, and publicprivate partnerships.

Figure 1 allows for a more comprehensive model overview. The coefficients are shown in blue, which means that they are all positive. In turn, the white color indicates zero coefficients, meaning that, in this case, no specific regressors are included in the true model. The horizontal axis is scaled by the models' posterior model probabilities. Figure 1 also shows the cumulative probability of the analyzed models (i.e., 500 best models), scaled by their PMPs.

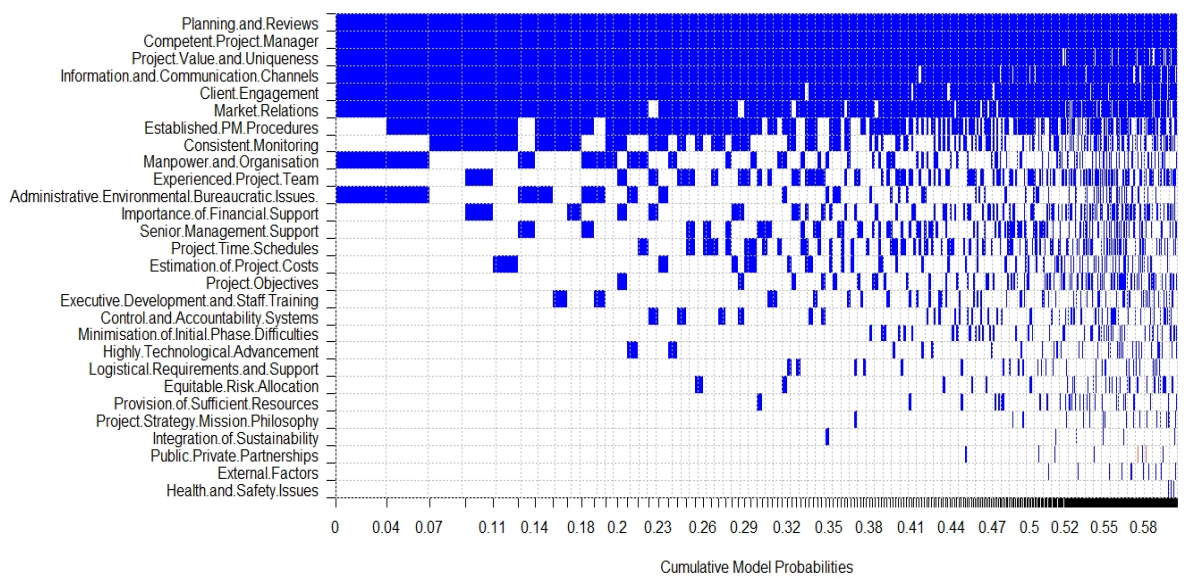

Figure 1. Model inclusion based on best 500 models. Source: authors' own elaboration.

More importantly, Figure 1 illustrates which regressors are most frequently incorporated into the true model, and whether they have stable coefficient signs (it can be seen that all regressors exhibit positive coefficients). It shows, for example, that the best model with the highest weight includes only the CSFs: planning and reviews, and competent project manager. Furthermore, it can be seen that these two variables are included in virtually all model space. On the other hand, external factors and health and safety issues and are rarely incorporated into the true model.

\section{Discussion}

In general, all 28 factors considered in this study seem to improve the performance of construction projects. However, certain reservation has to be made here. In the study, the endogenous variable (i.e., successful project completion) does not capture objective project evaluation criteria (i.e., hard numbers, e.g., number of projects completed on time, number of budget overruns, investments concluded and commissioned on time, reports with regards to customer satisfaction, etc.), because collecting such data for a large number of construction companies seems to be an almost impossible task and would certainly be very expensive- not to mention that it would be extremely time-consuming. This would probably require due diligence to be conducted in every company. Besides, not every construction company would be willing to provide such information for fear of its competition. Therefore, in the case of this study, only the perceptions of mid- and seniorlevel managers involved in construction project management were examined, in terms of 
their individual assessments of successes and the factors behind them. It can be assumed that the surveyed professionals know their work best and through years of experience and completed projects have learned what improves investment project performance and what does not. The study based on the BMA method allowed to systematize the existing knowledge and to make a ranking of preselected 28 factors that were most often mentioned in the literature. Moreover, each proposed CSF was justified by showing its relevance to Poland and the Polish context. The results of this study show that the eight most important factors are (1) planning and reviews, (2) competent project manager, (3) information and communication channels, (4) project value and uniqueness, (5) client engagement, (6) market relations, (7) established PM procedures, and (8) experienced project team. As a general rule, it can be concluded that success largely depends on good planning of all project processes and cyclical reviews of the progress of their realization. This is an absolute must. Moreover, it is consistent with what is presented in the papers by Kapliński [63] and Dziekoński [60]. If individual stages/processes of a specific project are poorly planned, it is difficult to expect any spectacular results. Planning is one of the five key functions of management according to Fayol [100], about which management students and future managers learn during their first year of studies. It is also worth noting that a similar conclusion was reached by Gudienè et al. [10] in a study conducted for Lithuania.

However, in order to realize various stages of an investment project, a good and proven project manager is irreplaceable since he/she coordinates all processes and is responsible for the whole course of the project. Similar conclusions are presented in the works of Grzesik and Piwowar-Sulej [61], and Podgórska and Pichalak [62]. Without a competent project manager, nothing can actually succeed (including the aforementioned good planning) and the management of every construction company must be aware of this. The results of this study show that the surveyed mid- and high-level managers are also aware of this fact. The importance of the project manager is particularly important for complex, large and highbudget projects, where even small mistakes can lead to budget overruns and significant delays. Hence the importance of appropriate risk allocation and the involvement of top management in the decision-making process, which, in a way, is also confirmed by the results of this study, showing that Senior Management Support (PIP $=0.3326)$, Project Time Schedules (PIP $=0.2603$ ), and Equitable Risk Allocation (PIP $=0.2556$ ) play a significant role, i.e., presenting medium evidential significance. In addition, appropriate information and communication channels must be ensured. The essence and importance of this investment project area is very strongly accentuated in the work of Kania et al. [67], who indicate that a well-designed communication and information sharing system must encompass general information about communication and information flow between construction project participants, problems in carrying out construction projects in relation to the lack of effective communication, the impact of communication on the success of carrying out the construction project, communication costs, and the need to develop a tool (a digital system) that would support construction project managers in the optimal control over communication between project participants. It is important to keep in mind that the environment in which modern construction companies operate is becoming ever more informative [5]. Managers have more and more data at their disposal (so-called big data) and are able to make use out of them. The project manager's ability to communicate tasks and receive feedback from his or her subordinates came out third in the study, with respect to the magnitude of the PIP. Moreover, PIPs above 0.5 are also associated with the following factors: project value and uniqueness, client engagement, market relations, established PM procedures, and experienced project team. This can be summarized as follows. Project value and uniqueness represent the added value and quality generated by an investment project. When implementing investment processes, it is absolutely necessary to increase such unique value as much as possible, because it determines the final assessment and client (end-user) satisfaction. Besides, as the results show, it is good to engage the clients (and the end-users) in the whole investment process, because their involvement in the whole project will make them more accountable for any possible mistakes and less susceptible 
to possible claims. Ultimately, the client's participation in the entire investment process translates into greater awareness and a sense of shared responsibility for possible execution errors. Arguably, clients who participate in the entire investment process from its inception to its conclusion are less likely to criticize and tend to be more appreciative towards the project itself. That is why this is so important. As far as the study results are concerned, they indicate that market relations and established project management procedures are the next most important factors. In terms of the former, maintaining good relations with all stakeholders seems to be obvious. This was emphasized in the work of Minzberg, for example [101]. The evidence of the importance of market relations for the success of construction projects was also confirmed in the study by Sobieraj and Metelski [22], where, in a similar questionnaire survey, market relations were indicated as one of the key factors contributing to the final success of the construction project. On the other hand, as far as project management procedures are concerned, they enforce a certain degree of project formalization, which allows for the streamlining of the project processes flow, without which it is difficult to maintain adequate coordination and control. This issue was highlighted in the papers by Pasławski and Jastrzab [69], and Hsino and Pasławski [81] who argue that developing appropriate standards (procedures, instructions, etc.) contributes to clarifying the existing rules of operation, and clear responsibilities. Unfortunately, in Polish conditions, excessively inflexible PM procedures may lead to difficulties in proper functioning of construction companies by limiting the initiative and creativity of their employees, by excessively bureaucratic rules, etc. The use of flexibility within management procedures can contribute to increased organizational efficiency and effectiveness through the ability to alter activities so as to accommodate changes in the environment. However, it is important to note that to some extent adhering to PM procedures is essential; it is also recommended in project management methodologies and standards [37] that were specifically created for this purpose. In other words, construction projects are typically complex and require some degree of formalization; otherwise, their success would be at risk of chaos and actually would be bound to fail beforehand.

The category of factors with strong evidence also includes a well-experienced team, which should be interpreted similarly to the importance of the role of the project manager. In general, the better the project manager and the more closely knit the team, the better it is for obvious reasons. In this respect, it is good for the team to be in tune with its project manager.

The medium evidence group comprises 15 factors. Some of them have already been mentioned above, e.g., equitable risk allocation, project time schedules, and senior management support. Of course, it is impossible to ignore such factors as the importance of financial support; consistent monitoring; manpower and organization; minimization of initial phase difficulties; control and accountability systems; executive development and staff training; provision of sufficient resources; project strategy, mission, and philosophy; estimation of project costs; administrative, environmental, and bureaucratic issues; and highly technological advancement. In fact, most of these factors do not require any special justification, as their role in project success appears to be obvious. However, at least one factor in this group deserves special emphasis, as its importance is not so often highlighted in the literature as in the case of other factors. Namely, it is the minimization of initial phase difficulties. The point is that the end of the initial phase is a key milestone for any construction project and, at the same time, a crucial point in time for a project to be scrutinized in order to rectify any deficiencies and improve the streamlining of the project in its further implementation phase [5]. Leaving significant shortcomings and errors at this stage of the project can result in far-reaching delays during its further phases and stages. It is therefore very important to take this milestone very seriously.

Finally, the group of factors that provide weak evidence cannot be ignored either, as their low PIPs do not necessarily mean that they lack relevance. These are such factors as health and safety issues, logistical requirements and support, integration of sustainability, external factors, and public-private partnerships. There is no doubt that they are important, 
although our study shows that the mid- and senior-level managers tend to prioritize what appear to be more strategic factors, which seems to be an understandable perspective. On the other hand, the project manager concentrates a lot of power in his hands and is responsible for many issues that in this study fall into the group of weak evidence, e.g., health and safety issues, logistical requirements and support, integration of sustainability, etc.

The novelty of this study lies on the combination of the focus on the CSFs that are relevant to Polish investment projects with the choice of analysis approach, which is BMA. More importantly, the research method that has been used in this study addresses the uncertainty that arises at the model selection stage. More specifically, the BMA approach allows us to analyze the whole set of all possible models, which results in estimating the most accurate model parameters (i.e., regression coefficients).

Insofar as the body of practice is concerned the knowledge of the hierarchy of importance of the factors describing the reality on the Polish construction market may help construction organizations to manage their projects and, hopefully, to make more conscious project decisions.

\section{Conclusions and Limitations}

This paper focuses on those CSFs that have been most frequently cited in the world and Polish literature. For this purpose, an in-depth review of the literature of successful investment project management was performed. Each proposed CSF was justified by showing its relevance to Poland and the Polish context. The choice of the research method was not arbitrary. It is acknowledged that the specificity of investment projects in Poland, i.e., their uniqueness and high degree of complexity of investment processes, determine the multiplicity of factors behind their successful completion or failure. This results in the fact that there are many similar lists of CSFs, and, in fact, every researcher presents a different set of CSFs, to the extent that it is difficult to find a consensus in this regard. This should not come as a surprise to anyone, since every researcher chooses a specific model from an unlimited space of different models and evaluates the phenomenon under study on its basis. Put differently, the common practice in empirical research is based on selecting a single model after what amounts to a search in the space of all possible models [102]. A study that is conducted in this way, however, turns out to be subjective to some extent, and therefore deserves nuanced critique and must be assessed with a grain of salt. The research method that was used in this study addresses the uncertainty that arises at the model-selection stage. More specifically, the BMA approach allowed us to analyze the whole set of all possible models, which results in estimating the most relevant model parameters (i.e., regression coefficients).

Taking the above into account, the study identified a number of CSFs for investment projects in Poland that constitute the best combination of parameters in the space of all possible models, and hence their PIPs are the highest. More specifically, the study shows that the highest-rated CSFs for construction projects in Poland are (1) planning and reviews, (2) competent project manager, (3) information and communication channels, (4) project value and uniqueness, (5) client engagement, (6) market relations, (7) established PM procedures, and (8) experienced project team.

To sum up, the paper seeks to systematize knowledge in the field of investment project management (with a particular focus on their successful completion) by conducting and analyzing the results of a survey of construction managers and by using appropriate research approaches to assess what industry professionals themselves consider important, i.e., what works and what can help in the management of buildings and the wider built environment. In this regard, greater knowledge gives construction companies increased capabilities in managing investments in a challenging competitive environment and broadens their scope to influence investment processes. Access to knowledge is essential for construction companies to succeed in the industry and remain competitive in the global marketplace. For example, one of the important CSFs that is addressed in this study (and is considered important in the context of the wider built environment) is the need to involve 
the client and the end-user(s) in the whole investment process, in order to minimize the costs of investment implementation and increase the value for the end client, which then reduces the costs associated with the in-use phase of the buildings/facilities. According to Sobieraj $[5,8]$, the end-user of buildings is supposed to have a professional system for managing commissioned buildings/facilities so as to maintain their technical efficiency, their related infrastructure, and their surroundings at an economically justified level of the costs of their ongoing operation. The costs must be affordable and acceptable to the end-users. Therefore, the inclusion of the client/investor and the end-user in the whole investment process facilitates the integration of the buildings' exploitation phase into the whole investment process. This is just one example of the applicability of the CSFs covered in this study, but, of course, each separate CSF in some way contributes to the improvement of the whole building process, which also includes the in-use phase.

It is recommended to carry out another study in which a more objective criterion for assessing projects could be applied, such as hard measures of success or failures, e.g., number of projects completed on time, number of budget overruns, investments completed and commissioned on time, client satisfaction, etc., but collecting such data for a large number of companies would be difficult and probably very expensive, let alone the timeframe for such an undertaking. On the other hand, recourse to objective success criteria would increase the overall credibility and applicability of the results.

Furthermore, one of the limitations of the research method employed in this study is the risk of its application in a non-optimal way, e.g., by making wrong assumptions about the priors. Hence, there is a common tendency to overestimate the conclusions drawn from the Bayesian model averaging, for example, in terms of both its strength and the validity of the results.

Author Contributions: Conceptualization, J.S. and D.M.; methodology, D.M.; validation, J.S.; investigation, J.S. and D.M.; resources, J.S. and D.M.; writing —original draft preparation, J.S. and D.M.; writing - review and editing J.S. and D.M.; visualization, D.M.; supervision, J.S. Both authors have read and agreed to the published version of the manuscript.

Funding: This research received no external funding.

Institutional Review Board Statement: Not applicable.

Informed Consent Statement: Informed consent was obtained from all subjects involved in the study.

Data Availability Statement: Raw data were generated from the Department of Building Engineering (Warsaw University of Technology). We confirm that the data, models, and methodology used in the research are proprietary, and the derived data supporting the findings of this study are available from the first author on request.

Conflicts of Interest: The authors declare no conflict of interest.

\section{Appendix A}

In this section, we present the questionnaire questions with associated numbers of responses in each category of the seven-point Likert-scale. 
Table A1. Questionnaire questions and numbers of responses in each 7-point Likert-scale category.

\begin{tabular}{|c|c|c|c|c|c|c|c|c|}
\hline \multirow[t]{2}{*}{ Variable No. } & \multirow[t]{2}{*}{ Questionnaire Question } & \multicolumn{7}{|c|}{$\begin{array}{l}\text { Number of Responses for a Given } \\
\text { 7-Point-Likert-Scale Category }\end{array}$} \\
\hline & & 1 & 2 & 3 & 4 & 5 & 6 & 7 \\
\hline 1 & $\begin{array}{l}\text { Do you agree that precise and timely identification of } \\
\text { project objectives has a significant impact on successful } \\
\text { project conclusion in your company? }\end{array}$ & 2 & 10 & 9 & 29 & 52 & 64 & 31 \\
\hline 2 & $\begin{array}{l}\text { Do you agree that health and safety issues have a } \\
\text { significant impact on project success in your company? }\end{array}$ & 2 & 4 & 4 & 25 & 64 & 79 & 19 \\
\hline 3 & $\begin{array}{l}\text { In your opinion, do timely planning and reviews } \\
\text { contribute to project success in your company? }\end{array}$ & 4 & 7 & 3 & 47 & 66 & 55 & 15 \\
\hline 4 & $\begin{array}{l}\text { Do you agree that provision of sufficient resources } \\
\text { leads to successful project completion in } \\
\text { your company? }\end{array}$ & 3 & 5 & 7 & 37 & 64 & 58 & 23 \\
\hline 5 & $\begin{array}{l}\text { How highly do you rate the role of information and } \\
\text { communication channels in terms of successful project } \\
\text { completion in your company? }\end{array}$ & 0 & 2 & 6 & 12 & 72 & 89 & 16 \\
\hline 6 & $\begin{array}{l}\text { Do you agree that administrative, environmental, and } \\
\text { bureaucratic issues have an important impact on your } \\
\text { company's successful project completion? }\end{array}$ & 3 & 6 & 13 & 59 & 77 & 25 & 14 \\
\hline 7 & $\begin{array}{l}\text { How important are control and accountability systems } \\
\text { for successful project completion in your company? }\end{array}$ & 4 & 2 & 0 & 8 & 18 & 74 & 91 \\
\hline 8 & $\begin{array}{l}\text { How large is the extent to which external factors (such } \\
\text { as weather conditions, random events, strikes, labor } \\
\text { disputes, etc.) exert an influence on successful project } \\
\text { completion in your company? }\end{array}$ & 3 & 2 & 3 & 12 & 67 & 62 & 48 \\
\hline 9 & $\begin{array}{l}\text { In your opinion, is the focus on value and uniqueness } \\
\text { of projects an important element for successful project } \\
\text { completion in your company? }\end{array}$ & 4 & 2 & 12 & 15 & 57 & 71 & 36 \\
\hline 10 & $\begin{array}{l}\text { Does the use of highly technological advancements } \\
\text { impact your company's project successes? }\end{array}$ & 5 & 10 & 12 & 44 & 100 & 22 & 4 \\
\hline 11 & $\begin{array}{l}\text { Do you agree that equitable risk allocation significantly } \\
\text { impacts your company's project successes? }\end{array}$ & 0 & 7 & 16 & 32 & 49 & 74 & 19 \\
\hline 12 & $\begin{array}{l}\text { In your opinion, does project cost estimation play an } \\
\text { important role in project success and successful project } \\
\text { completion in your company? }\end{array}$ & 5 & 7 & 16 & 74 & 68 & 24 & 3 \\
\hline 13 & $\begin{array}{l}\text { Do you agree that having an experienced project team } \\
\text { is crucial to project success and successful project } \\
\text { completions in your company? }\end{array}$ & 2 & 2 & 17 & 67 & 101 & 2 & 6 \\
\hline 14 & $\begin{array}{l}\text { Do you agree that implementing construction projects } \\
\text { under the Public-Private Partnerships model, increases } \\
\text { the chances of successful project completion in } \\
\text { your company? }\end{array}$ & 1 & 2 & 8 & 21 & 85 & 49 & 31 \\
\hline 15 & $\begin{array}{l}\text { Does successful project completion in your company } \\
\text { require a focus on overcoming the difficulties that arise } \\
\text { during the project's initial phase? In other words, do } \\
\text { you agree that the minimization of initial phase } \\
\text { difficulties is reflected in project results? }\end{array}$ & 2 & 4 & 8 & 18 & 95 & 62 & 8 \\
\hline
\end{tabular}


Table A1. Cont.

\begin{tabular}{|c|c|c|c|c|c|c|c|c|}
\hline \multirow{2}{*}{ Variable No. } & \multirow[t]{2}{*}{ Questionnaire Question } & \multicolumn{7}{|c|}{$\begin{array}{l}\text { Number of Responses for a Given } \\
\text { 7-Point-Likert-Scale Category }\end{array}$} \\
\hline & & 1 & 2 & 3 & 4 & 5 & 6 & 7 \\
\hline 16 & $\begin{array}{l}\text { In your opinion, does maintaining the integration of } \\
\text { sustainability into construction projects result in } \\
\text { successful project completion for your company? }\end{array}$ & 6 & 2 & 0 & 12 & 36 & 81 & 60 \\
\hline 17 & $\begin{array}{l}\text { To what extent do you agree that an emphasis on } \\
\text { manpower and organization is an important element } \\
\text { reflected in project results? }\end{array}$ & 7 & 6 & 2 & 16 & 63 & 71 & 32 \\
\hline 18 & $\begin{array}{l}\text { To what extent does senior management support play } \\
\text { an important role in the successful completion of } \\
\text { projects in your company? }\end{array}$ & 9 & 7 & 20 & 65 & 65 & 24 & 7 \\
\hline 19 & $\begin{array}{l}\text { Given your previous experience, do you agree that } \\
\text { financial support for an investment project and } \\
\text { securing suitable funding for its implementation are } \\
\text { the key areas determining its successful completion } \\
\text { (taking into account your company's experience)? }\end{array}$ & 5 & 4 & 11 & 52 & 84 & 35 & 6 \\
\hline 20 & $\begin{array}{l}\text { To what extent do you agree that executive } \\
\text { development and staff training are important } \\
\text { contributors to project success in your company? }\end{array}$ & 6 & 3 & 10 & 20 & 80 & 69 & 9 \\
\hline 21 & $\begin{array}{l}\text { Do you agree that established project management } \\
\text { procedures contribute to the success of investment } \\
\text { projects in your company? }\end{array}$ & 0 & 5 & 6 & 24 & 69 & 68 & 25 \\
\hline 22 & $\begin{array}{l}\text { Do you agree that client engagement in the entire } \\
\text { investment process is key to project success and } \\
\text { successful project completion (taking into account your } \\
\text { company's experience)? }\end{array}$ & 6 & 8 & 11 & 46 & 69 & 48 & 9 \\
\hline 23 & $\begin{array}{l}\text { In your opinion, are the project strategy, mission, and } \\
\text { philosophy important aspects of the investment } \\
\text { process, reflected in the success of projects in } \\
\text { your company? }\end{array}$ & 2 & 4 & 4 & 4 & 42 & 87 & 54 \\
\hline 24 & $\begin{array}{l}\text { Do you agree that project logistical requirements and } \\
\text { support are important elements that are reflected in } \\
\text { project results, and consequently influence which } \\
\text { projects become successful (taking into account your } \\
\text { company's experience)? }\end{array}$ & 8 & 6 & 18 & 64 & 76 & 20 & 5 \\
\hline 25 & $\begin{array}{l}\text { Do you agree that maintaining appropriate market } \\
\text { relations plays a significant role in your company's } \\
\text { successful project completion? }\end{array}$ & 4 & 1 & 3 & 6 & 45 & 59 & 79 \\
\hline 26 & $\begin{array}{l}\text { Do you agree that creating appropriate project time } \\
\text { schedules plays a significant role in your company's } \\
\text { successful project completion? }\end{array}$ & 3 & 6 & 14 & 18 & 78 & 47 & 31 \\
\hline 27 & $\begin{array}{l}\text { In your opinion, does consistent monitoring of ongoing } \\
\text { investment processes significantly translate into project } \\
\text { successes in your company? }\end{array}$ & 3 & 6 & 5 & 39 & 61 & 81 & 2 \\
\hline 28 & $\begin{array}{l}\text { How strongly are the competencies of the project } \\
\text { manager reflected in the project successes achieved by } \\
\text { your company? }\end{array}$ & 1 & 7 & 6 & 47 & 75 & 53 & 8 \\
\hline
\end{tabular}


Table A2. List of variables used in the analysis and their relevance in the Polish context.

\begin{tabular}{cl}
\hline Variable & \multicolumn{1}{c}{ Name of Variable } \\
\hline$X_{1}$ & $\begin{array}{l}\text { Key competences and high } \\
\text { authority of the project manager }\end{array}$ \\
& \\
\hline$X_{2}$ & $\begin{array}{l}\text { Timely project planning and } \\
\text { reviews (organizing cyclical } \\
\text { meetings to assess } \\
\text { project progress) }\end{array}$ \\
\hline$X_{3}$ & $\begin{array}{l}\text { Selection of an adequate and } \\
\text { competent project team with } \\
\text { relevant past experience } \\
\text { (commitment of project teams in } \\
\text { reaching project objectives) }\end{array}$ \\
\hline
\end{tabular}

Dziekoński [60] points to the strong relationship between project success and the project manager's skills. In his study based on a survey conducted among members of the Polish Chamber of Construction, he proposes a construction project manager competencies model based on the clustering method, which allowed for a broader understanding of how construction engineers' personal skills, knowledge and abilities translate into project performance. Grzesik and Piwowar-Sulej [61] studied 100 organizations located in Poland, of which some were project-oriented construction companies. Their aim was to explore the issue of project manager competencies and project leadership styles in project-oriented organizations such as construction companies. In order to present the determinants influencing the image obtained on the basis of the discussed competencies and leadership styles, it seems justified to conduct further exploratory research in this regard. Podgórska and Pichlak [62] provided empirical support for the influence of project managers' leadership competencies, and their emotional and managerial skills on project success in the Polish context.

The usefulness of planning techniques and decision-making foundations in the context of construction projects in Poland was accentuated by Kapliński [63]. The role of project planning and reviews with regards to investment projects was also explored by Dziekoński [60], Sobieraj [5], and Sobieraj and Metelski [22].

Sobieraj, Metelski and Nowak [37] emphasize the importance of appropriate selection of investment project teams as an important factor translating into project results. It should be remembered that project teams are composed of particular individuals who are involved in the actual implementation of a given project and they are entrusted with specific authorizations and responsibilities.

A thorough analysis of communication and information flow within construction projects realized in Poland can be found in the study by Kania et al. [67]. In a nutshell, communication and information channels, have a direct impact on the time and cost of a construction project. The authors, in reference to global studies, present

Adequate communication and provision of information,

$X_{4} \quad$ information channels (dissemination of information about project implementation) the results of a survey study performed in Poland on a group of 160 construction industry practitioners. It collated information on five research areas, which included the following: general information about communication and information flow between construction project participants, problems in carrying out construction projects in relation to the lack of effective communication, the impact of communication on the success of carrying out a construction project, communication costs, and the need to develop a tool (a digital system) that would support construction project managers in the optimal control over communication between project participants.

The importance of the control of work progress throughout the whole project is addressed in the paper by Kapliński et al. [68]. The issue of control of work progress throughout the whole project (realized in Poland) is addressed in the paper by Kapliński et al. [63], and Leśniak and Zima [78].
$X_{5}$
Control and accountability systems

Sobieraj and Metelski [22] in a survey of Polish construction managers indicate as many as 5 factors related to various forms of monitoring, i.e., monitoring the country's economic situation, the environment, the emergence of new building technologies, building materials market, and monitoring the performance of competitors.

Sobieraj and Metelski [22] point to the necessity of setting unambiguous project objectives, indicating this factor as one of the 71 used in the survey conducted among Polish construction managers. 
Table A2. Cont.

\begin{tabular}{|c|c|c|}
\hline Variable & Name of Variable & Relevance to Poland \\
\hline$X_{8}$ & External factors & $\begin{array}{l}\text { Pasławski and Jastrzab [69] highlight the importance of external factors in the } \\
\text { context of Polish investment project. More specifically, they address four groups of } \\
\text { factors that are pivotal with regards to possible disturbances which may arise } \\
\text { during the implementation of an investment project: related to the investor (e.g., } \\
\text { change in the scope of the project, etc.), related to the designer (e.g., documentation } \\
\text { errors), related to the contractors (e.g., related to the labor force), and related to the } \\
\text { environmental impact (e.g., weather-related). Sobieraj and Metelski [22] view } \\
\text { external factors as those that can influence the course of an investment project and } \\
\text { ultimately determine its success or failure. The authors addressed these factors in a } \\
\text { survey conducted among managers and experts from the Polish construction } \\
\text { industry, and analyzed them by means of the exploratory factor analysis. Both } \\
\text { analyses of individual processes and entire projects show that changes in the } \\
\text { environment can lead to impediments in the realization of investment projects (e.g., } \\
\text { legal problems, lowered quality, budget overruns, failure of the entire project, etc.) } \\
\text { and to a significant deviation from the originally planned deadlines } \\
\text { for their completion [70-72]. }\end{array}$ \\
\hline
\end{tabular}

Sobieraj $[5,8]$ defines the provision of resources as the totality of processes associated with the realization of an investment project on the construction site. It comprises the following activities: (1) conceptual processes; (2) planning of construction works; (3) determination of the work breakdown structure; (4)

$\mathrm{X}_{9} \quad$ Provision of sufficient resources scheduling of activities and subsequent analysis of schedules (already confronted with the progress of activities on the construction site, as well as their regular weekly updates); (5) use of timescale charts in the management process; (6) time control, which is an alternative to scheduling; and (7) issues related to resource constraints and distribution, and performing resource valuation.

Sobieraj [8] posits that many construction project managers have the belief that if they develop the right strategy or business plan for an investment project, the project teams will develop and implement such right strategy as expected. However, project teams are often left on their own, with only minimal advice and assistance from senior management. Sobieraj, Metelski, and Nowak [37] bring up the issue of the support and greater involvement of senior management in the context of investment projects realized in Poland. The authors note that usually such support is greater in those projects that are relying on the PRINCE2 methodology.

Sobotka and Czarnigowska [74] address a number of problems in construction project logistics, with particular emphasis on the provision systems. The results of a survey conducted among Polish construction companies show that establishing appropriate logistical systems can significantly reduce the costs of investment

Logistical requirements and $X_{11} \quad$ support of the construction backup facilities projects. Creating project logistics assumptions early in the project planning stage and then designing an integrated project logistics service can help increase the efficiency of a construction project.

Sobieraj [8] points to the distinctive role of project schedules under the conditions of Polish investment processes, and stresses that many complicated situations that are likely to occur during the course of an investment project can be anticipated and adequately protected against, e.g., by assuming additional time for their resolution or by effectively managing risks in the time schedules and cost estimates. It is also worth considering the use of proven solutions that are used in other countries.

Project time schedules and detailed project description and

$X_{12} \quad$ specification of the various stages of project implementation and any predictable events between its stages These include long and thorough preparation of the investment, development of variants for its implementation, as well as introduction of standardization of engineering documentation. Moreover, in another study Sobieraj and Metelski [22] employ "time schedule and detailed specification of the various stages of project implementation" as one of the variables in a study based on the exploratory factor analysis. The role of time schedules was also explored in the work of Jaśkowski and Biruk [76], who proposed a method of improving the construction schedule reliability, and in the paper by Leśniak and Plebankiewicz [73] who argue that delays in the execution of construction works and extensions of investment schedules are a common phenomenon today, despite the existence of modern technologies and tools that are supposed to prevent such occurrences. 
Table A2. Cont.

\begin{tabular}{|c|c|c|}
\hline Variable & Name of Variable & Relevance to Poland \\
\hline$X_{13}$ & $\begin{array}{l}\text { Executive development and } \\
\text { staff training }\end{array}$ & $\begin{array}{l}\text { The need for knowledge building in the context of investment projects in Poland } \\
\text { was addressed in the works of Sobieraj [5], Sobieraj, Metelski, and Nowak [37] and } \\
\text { Sobieraj and Metelski [22]. }\end{array}$ \\
\hline$X_{14}$ & Manpower and organization & $\begin{array}{l}\text { Sobieraj [5], and Sobieraj and Metelski [22] indicate "qualified and mobile labour } \\
\text { force", and "availability of trained workers on sites" as those factors that improve } \\
\text { the results of investment projects. }\end{array}$ \\
\hline$X_{15}$ & $\begin{array}{l}\text { Importance financial support, } \\
\text { sufficient project funding and } \\
\text { financial management }\end{array}$ & $\begin{array}{l}\text { The importance of financial support for construction projects is highlighted in the } \\
\text { work of Kaplinski et al. [68]. The authors address the issue of financing in the } \\
\text { context of the risk factors associated with an investment project. Sobieraj and } \\
\text { Metelski [22], in a study on industrial construction projects, indicate factors } \\
\text { associated with investment financing, and more specifically, with the availability of } \\
\text { the sources of investment financing, as the ones that bring about success of failure of } \\
\text { an investment project. Sobieraj [8] points to the access to bank credits, public and } \\
\text { EU subsidies and bank guarantees to secure good performances of the agreements } \\
\text { and completion of investment projects on time. }\end{array}$ \\
\hline
\end{tabular}

Cost estimates are essential for the success of construction projects. The expectations of the construction industry are to shorten the time necessary to predict costs, whilst, $\begin{array}{ll}X_{16} & \begin{array}{l}\text { Accurate estimation of project } \\ \text { costs (cost efficiency) }\end{array}\end{array}$ on the other hand, the estimates must be reliable and accurate enough. For example, Juszczyk, Leśniak, and Zima [103] used state-of-the-art tools, such as artificial neural networks and data from 129 Polish construction projects, and presented their investigations on applicability of artificial neural networks for estimating the total cost of construction works.

Kulejewski [79] argues that when managing construction projects in Poland, insufficient importance is given to the role of the initial phase (including preparation and planning), and one should be aware that this is a relatively least costly phase. Moreover, Sobieraj $[5,80]$ notices that the role of the initial phase in the management of projects (including preparation and planning) should be given greater attention, since it is the relatively least costly phase. With good project preparation and planning, costly mistakes and unnecessary problems can be avoided during the implementation phase. During the initial phase of an investment project it is still possible to abandon the whole project without unnecessary further costs, e.g., related to land purchase, if its implementation is burdened with an excessive risk or exceeds the financial capacity of the investor or is simply unprofitable (economically unjustified).

Hsino and Pasławski [81] notice that developing appropriate standards (procedures, instructions, etc.) contributes to clarifying the existing rules of operation, and clear responsibilities. Unfortunately, in Polish conditions, PM procedures that are unnecessarily inflexible may lead to difficulties in proper functioning, as they may limit the initiative and creativity of employees, or may force employees to comply with overly bureaucratic rules, etc. The use of flexibility within management procedures can contribute to increased organizational efficiency and effectiveness through the ability to alter activities in order to accommodate changes in the environment.

Project strategy that combines individual and group skills to

$X_{19} \quad$ achieve the best balance of resources available at the right time

Clients (end-users) engaged in the project management activities at an executive level, as they are the ones who have a view of the project in its holistic context
Project strategy, mission, and philosophy are very important issues that are completely neglected in the literature. They are related to defining the specificity, scope and conditions of strategic project management at the project team level. The division of strategic tasks is conditioned by the autonomy of the project, the time perspective of project realization, and the degree of its innovativeness [82].

Sobieraj [5] argues clients and end-users have to be actively involved in the entire decision-making process of an investment project. Project teams closely respond to the needs of clients by providing them with what constitutes the real added value. Thanks to this approach, on the one hand, the project team learns what is of value in a given project, on the other hand, the recipients of projects' products (clients and end-users) can expect to get exactly what is valuable for them. 
Table A2. Cont.

\begin{tabular}{|c|c|c|}
\hline Variable & Name of Variable & Relevance to Poland \\
\hline$X_{21}$ & $\begin{array}{l}\text { Importance of public-private } \\
\text { partnerships (PPPs) }\end{array}$ & $\begin{array}{l}\text { Realization of investment projects under the PPP model has become very popular in } \\
\text { Poland in recent years. Sobieraj [5] discusses this issue in great depth relying on the } \\
\text { case of the construction of a housing estate in Bemowo in Warsaw, as an example of } \\
\text { the successful public-private partnership (PPP) project carried out in Poland. } \\
\text { Wegrzyn [85] addresses contemporary trends that are being developed in Poland in } \\
\text { the PPP model. The paper by Wegrzyn [85,86] builds on a larger research study } \\
\text { looking at the development of the best practice framework for PPPs. Her study } \\
\text { concentrates on one of the two dimensions of the PPP project success which is the } \\
\text { idea of critical success factors. According to Siemiatycki [83], an undoubted } \\
\text { advantage of construction projects carried out under PPP is their greater } \\
\text { transparency in terms of project documentation and the entire planning process, i.e., } \\
\text { owing to the fact that complete concession agreements and documents summarizing } \\
\text { the value of the project in relation to its price are made accessible to the public. }\end{array}$ \\
\hline
\end{tabular}

Kaplinski et al. [68] points to the importance of risk management, and more specifically to identification, analysis (especially quantitative) and reaction to risk allocation when managing investment projects in Poland. Among the basic types of risk, the time risk comes into the foreground (the risk of delays in concluding the construction investment due to various reasons, mostly external), and the financial risk (exceeding the costs of construction, inability to reach the envisaged returns, higher costs, etc.). Moreover, the risk-sided assessments of the investment projects in

$X_{22} \quad$ Equitable risk allocation (risk) Poland were addressed in the papers by Bryx [91] and Skorupka [87]. Moreover, a fairly advanced study on risks in the context of Polish construction projects can be found in the work of Bizon-Górecka and Górecki [88], Górski and Dziadosz [24], Turskis et al. [89], Szymański [90], and Sobieraj [5]. Dziadosz and Rejment [64] highlight the importance of the risks analysis for project selection and coordination of construction works. The risk analysis is regarded as the analysis of adverse events even at the stage of planning and programming of a construction project. This analysis enriches the decision-making process and provides additional arguments, which help to select the optimal variant of a construction project.

Sobieraj and Metelski [77] studied the impact of state policies on investment project management in the industrial construction sector in Poland. They conducted a

Legal-administrative and

$X_{23}$ environmental issues, bureaucracy survey in which took part 158 Polish companies dealing with industrial construction projects, and came to the conclusion that successful completion of such investment projects is influenced by properly shaped and stable economic, environmental and legal policies of the state.

Górecki and Diaz-Madronero [93] point to the rising demands of the key market players who insist on making construction projects more sustainable according to the simultaneous improvement of the economic, environmental and social responsiveness dimensions. The authors conducted a survey among construction experts from Northern Poland to detect their subjective perspectives about risk costs and analyze the corresponding costs structure for the investment in sustainable projects. The issue of integrating sustainability into construction projects was studied by Michalak and Michalowski [94], who conducted a survey among 842 respondents who were investors, architects, contractors, and building-material vendors. The survey was designed to illustrate their perception of the issues related to the concept of sustainable development and their knowledge of selected documents applicable in the construction industry.

Górny [6] studied the construction projects realized in Poland with regards to health and safety issues. He stresses that there is a wide range of quality engineering instruments available that allow minimizing these issues (e.g., accident-related delays, downtime costs, etc.), and which consequently increase the performance of

$X_{25} \quad$ Health and safety issues construction projects. In his opinion, the most important issue for project teams is to ensure their ability to process the available information and implement appropriate measures and improvement solutions in order to achieve effective results and continuously adapt to the changing environment. Achieving benefits depends on using the right tools to gather information and identify areas of improvement [104]. 
Table A2. Cont.

\begin{tabular}{cll}
\hline Variable & \multicolumn{1}{c}{ Name of Variable } & \multicolumn{1}{c}{ Relevance to Poland } \\
\hline$X_{26}$ & $\begin{array}{l}\text { Project value (quality) and } \\
\text { uniqueness }\end{array}$ & $\begin{array}{l}\text { Sobieraj [5] notices that project management practitioners tend to define project } \\
\text { success as a delivery of perceived customer value. }\end{array}$ \\
\hline$X_{27}$ & $\begin{array}{l}\text { Complications in the formation } \\
\text { of market relations }\end{array}$ & $\begin{array}{l}\text { The importance of market relations in the Polish context is thoroughly addressed in } \\
\text { the works of Sobieraj [5], and Sobieraj and Metelski [22]. }\end{array}$ \\
\hline \multirow{2}{*}{$\begin{array}{l}\text { Highly technological } \\
\text { advancement }\end{array}$} & $\begin{array}{l}\text { Kaplinski et al. [68] point out the need for a multidirectional approach to the issues } \\
\text { of mechanization and automation of work processes carried out during the erection } \\
\text { of various structures and buildings. The multi-tasking in construction project } \\
\text { requires the use of advanced technologies, including a variety of machines and } \\
\text { equipment of different types, purpose, size and power. According to Sobieraj [5], } \\
\text { Polish construction companies need to equip themselves with modern technologies } \\
\text { and implement innovations, and more importantly they ought to invest in } \\
\text { construction technologies that are functionally coherent with the idea of automation } \\
\text { and robotization of construction processes. Finally, Sobieraj and Metelski [22] } \\
\text { address highly technological advancement in their study based on a survey of the } \\
\text { top-level managers from Polish construction companies. }\end{array}$ \\
\hline
\end{tabular}

Source: authors' own elaboration.

\section{References}

1. Central Statistical Office. Construction in 2019. 2020. Available online: https://stat.gov.pl/obszary-tematyczne/przemyslbudownictwo-srodki-trwale/budownictwo/budownictwo-w-2019-roku,13,5.html (accessed on 20 June 2021).

2. Bridge Group. Polish Construction Industry in 2009-2019. The State of Safety and Activities of the Alliance for Safety in Construction. Available online: http://www.porozumieniedlabezpieczenstwa.pl/images/baza_wiedzy/raport/Budownictwo_ polskie_w_latach_2009_-_2019_-_raport.pdf (accessed on 2 August 2021).

3. Pępek, T. Bezpieczeństwo Pracy w Budownictwie w 2020 roku. Available online: https://www.oknonet.pl/news/news,31467,w, bezpieczenstwo-pracy-w-budownictwie-w-2020-roku.html (accessed on 2 August 2021).

4. Jaki, A.; Ćwięk, W. Value creation efficiency of Polish construction companies listed on Warsaw Stock Exchange during 2010-2012. Int. J. Bus. Perform. Manag. 2020, 21, 214-229. [CrossRef]

5. Sobieraj, J. Investment Project Management on the Housing Construction Market; Universidad de Granada, Universitas Aurum Grupo Hespérides: Madrid, Spain, 2020.

6. Górny, A. Guidelines for the Use of Quality Engineering Tools to Improve Occupational Safety. The Case of Polish Construction Companies. In Occupational and Environmental Safety and Health II. Studies in Systems, Decision and Control; Arezes, P., Baptista, J.S., Barroso, M.P., Carneiro, P., Cordeiro, P., Costa, N., Melo, R.B., Abreu dos Santos Baptista, J.M., Perestrelo, G., Eds.; Springer: Cham, Switzerland, 2020; Volume 277. [CrossRef]

7. Rozkrut, M.; Kowalczyk, A.; Boguszewski, R. Raport z Badania Sektora Budowlanego 2019; BGK: Warsaw, Poland, 2020.

8. Sobieraj, J. Wptyw Polityki Gospodarczej, Środowiskowej i Prawnej na Zarzadzanie Procesem Inwestycyjnym w Budownictwie Przemysłowym; ITE-PIB: Radom, Poland, 2019.

9. Czechowska. Podsumowujemy Rynek Budowlany w Roku 2019. Co Czeka Rynek Budowlany w Roku 2020? 2019. Available online: https: / / www.muratorplus.pl/biznes/raporty-i-prognozy/dobre-prognozy-dla-branzy-budowlanej-aa-9wie-eQdmvNKB.html (accessed on 17 June 2021).

10. Gudienè, N.; Banaitis, A.; Podvezko, V.; Banaitienè, N. Identification and evaluation of the critical success factors for construction projects in Lithuania: AHP approach. J. Civ. Eng. Manag. 2014, 20, 350-359. [CrossRef]

11. Garbharran, H.; Govender, J.; Msani, T. Critical success factors influencing project success in the construction industry. Acta Structilia 2012, 19, 90-108.

12. Spałek, S. Critical Success Factors in Project Management; Publshing House of the Silesian University of Technology: Gliwice, Poland, 2004.

13. Al-Tmeemy, S.M.H.M.; Abdul-Rahman, H.; Harun, Z. Future criteria for success of building projects in Malaysia. Int. J. Proj. Manag. 2010, 29, 337-348. [CrossRef]

14. Yong, Y.C.; Mustaffa, N.E. Analysis of factors critical to construction project success in Malaysia. Eng. Constr. Archit. Manag. 2012, 19, 543-556. [CrossRef]

15. Yong, Y.C.; Mustaffa, N.E. Critical success factors for Malaysian construction projects: An empirical assessment. Constr. Manag. Econ. 2013, 31, 959-978. [CrossRef]

16. Zavadskas, E.K.; Vilutienè, T.; Turskis, Z.; Šaparauskas, J. 2014. Multi-criteria analysis of projects' performance in construction. Arch. Civ. Mech. Eng. 2014, 14, 114-121. [CrossRef]

17. Zavadskas, E.K.; Vainiūnas, P.; Turskis, Z.; Tamošaitienè, J. Multiple criteria decision support system for assessment of projects managers in construction. Int. J. Inf. Technol. Decis. Mak. 2012, 11, 501-520. [CrossRef] 
18. Zavadskas, E.K.; Kaklauskas, A. Multi-Objective Selection for Decisions in Construction; IRB Verlag: Stuttgart, Germany, 2007.

19. Meng, X.; Boyd, P. The role of the project manager in relationship management. Int. J. Proj. Manag. 2017, 35, 717-728. [CrossRef]

20. Nixon, P.; Harrington, M.; Parker, D. Leadership performance is significant to project success or failure: A critical analysis. Int. J. Product. Perform. Manag. 2012, 61, 204-216. [CrossRef]

21. Yang, L.R.; Huang, C.F.; Wu, K.S. The association among project manager's leadership style, teamwork and project success. Int. J. Proj. Manag. 2011, 29, 258-267. [CrossRef]

22. Sobieraj, J.; Metelski, D. Identification of the key investment project management factors in the housing construction sector in Poland. Int. J. Constr. Manag. 2020, 1-12. [CrossRef]

23. Sayles, L.; Chandler, M. The Project Manager: Organizational Metronome; Harper \& Row: New York, NY, USA, 1971; pp. $204-226$.

24. Górski, M.; Dziadosz, A.; Skorupka, D. Risk management in construction projects under the PRINCE2 methodology. Sci. Pap. Gen. T. Kosciuszko Mil. Acad. Land Forces 2010, 157, 41-53.

25. Ahmed, R.; Azmi, N.; Masood, T.; Tahir, M.; Ahmad, M.S. What does project leadership really do? Int. J. Sci. Eng. Res. 2013, 4 , $1-8$.

26. Ibrahim, K.I.; Costello, S.B.; Wilkinson, S. Key practice indicators of team integration in construction projects: A review. Team Perform. Manag. 2013, 19, 132-152. [CrossRef]

27. Aksorn, T.; Hadikusumo, B.H.W. Critical success factors influencing safety program performance in Thai construction projects. Saf. Sci. 2008, 46, 709-727. [CrossRef]

28. Al Haadir, S.; Panuwatwanich, K. Critical success factors for safety program implementation among construction companies in Saudi Arabia. Procedia Eng. 2011, 14, 148-155. [CrossRef]

29. Ismail, Z.; Doostdar, S.; Harun, Z. Factors influencing the implementation of a safety management system for construction sites. Saf. Sci. 2012, 50, 418-423. [CrossRef]

30. Jaselskis, E.J.; Anderson, S.D.; Russell, J.S. Strategies for achieving excellence in construction safety performance. J. Constr. Eng. Manag. 1996, 122, 61-70. [CrossRef]

31. Memon, A.H.; Rahman, I.A.; Aziz, A.A.A.; Abdullah, N.H. Using structural equation modelling to assess effects of construction resource related factors on cost overrun. World Appl. Sci. J. 2012, 21, 6-15. [CrossRef]

32. Doloi, H.; Sawhney, A.; Iyer, K.C.; Rentala, S. Analysing factors affecting delays in Indian construction projects. Int. J. Proj. Manag. 2012, 30, 479-489. [CrossRef]

33. Ghoddousi, P.; Hosseini, M.R. A survey of the factors affecting the productivity of construction projects in Iran. Technol. Econ. Dev. Econ. 2012, 18, 99-116. [CrossRef]

34. Bentley, C. Prince2: A Practical Handbook; Routledge: New York, NY, USA, 2012.

35. Kiani, S.; Yousefi, V.; Nouri, S.; Khadivi, A.M.; Mehrabanfar, E. Determining the Role of Project Management Office in the Success of Project-Based Organizations. Mediterr. J. Soc. Sci. 2015, 6, 325. [CrossRef]

36. Tafazzoli, M.; Shrestha, P. Factor analysis of construction delays in the US construction industry. In Proceedings of the ASCE International Conference on Sustainable Infrastructure, New York, NY, USA, 26-28 October 2017; pp. 111-122.

37. Sobieraj, J.; Metelski, D.; Nowak, P. PMBoK vs. PRINCE2 in the context of Polish construction processes-projects. Arch. Civ. Eng. 2021, 67, 551-579. [CrossRef]

38. Muhammad, Z.; Johar, F. Critical success factors of public-private partnership projects: A comparative analysis of the housing sector between Malaysia and Nigeria. Int. J. Constr. Manag. 2019, 19, 257-269. [CrossRef]

39. Kabir, G.; Tesfamariam, S.; Sadiq, R. Bayesian model averaging for the prediction of water main failure for small to large Canadian municipalities. Can. J. Civ. Eng. 2016, 43, 233-240. [CrossRef]

40. Rockart, J.F. The changing role of the information systems executive: A critical success factors perspective. Sloan Manag. Rev. 1982, 24, 3-13.

41. Naoum, S.; Fong, D.; Walker, G. Critical success factors of project management. In Proceedings of the International Symposium on Globalisation and Construction AIT Conference Centre, Bangkok, Thailand, 17-19 November 2004; pp. 827-838.

42. Pinto, J.K.; Slevin, D.P. Critical factors in successful project implementation. IEEE Trans. Eng. Manag. 1987, 34, 22-27. [CrossRef]

43. Martin, C.C. Project Management: How to Make It Work; AMACOM: New York, NY, USA, 1976; p. 241.

44. Cleland, D.I.; King, W.R. Project Management Handbook, 3rd ed.; Rei: New York, NY, USA, 1983.

45. Baker, G.; Murphy, D.; Fisher, D. Factors affecting project management. In Project Management Handbook; Cleland, D.I., King, W.R., Eds.; Van Nostrand Reinhold: New York, NY, USA, 1997; pp. 669-685.

46. Locke, D. Project Management; St. Martin's Press: New York, NY, USA, 1984.

47. Sullivan, A.; Harris, F.C. Delays on large construction projects. Int. J. Oper. Prod. Manag. 1986, 6, 25-33. [CrossRef]

48. Odeyinka, H.A.; Yusif, A. The causes and effects of construction delays on completion cost of housing projects in Nigeria. $J$. Financ. Manag. Prop. Constr. 1997, 2, 31-44.

49. Standish Group. Chaos: A Recipe for Success. 1998. Available online: http://www.dsc.ufcg.edu.br/ \{\}garcia/cursos/ger_ processos/artigos/chaos1998.pdf (accessed on 2 June 2021).

50. Standish Group. Chaos Summary. 2009. Available online: https://www.classes.cs.uchicago.edu/archive/2014/fall/51210-1/ required.reading/Standish.Group.Chaos.2009.pdf (accessed on 2 June 2021).

51. Pan, W.; Dainty, A.R.; Gibb, A.G. Establishing and weighting decision criteria for building system selection in housing construction. J. Constr. Eng. Manag. 2012, 138, 1239-1250. [CrossRef] 
52. Hwang, B.G.; Ng, W.J. Project management knowledge and skills for green construction: Overcoming challenges. Int. J. Proj. Manag. 2013, 31, 272-284. [CrossRef]

53. Panibratov, J.; Larionov, A. Steady development of construction organization of housing profile. World Appl. Sci. J. 2013, 23, 144-148.

54. Ulubeyli, S.; Kazaz, A.; Soycopur, B.; Er, B. Quality function deployment in the speculative house-building market: How to satisfy high-income customers. Int. J. Constr. Manag. 2015, 15, 148-156. [CrossRef]

55. Jaafar, M.; Nuruddin, A.R.; Bakar, S.P.S.A. Managerial capabilities of housing developers: Building the competitive advantage of a firm. Int. J. Constr. Manag. 2016, 16, 27-38. [CrossRef]

56. Kavishe, N.; Jefferson, I.; Chileshe, N. Evaluating issues and outcomes associated with public-private partnership housing project delivery: Tanzanian practitioners' preliminary observations. Int. J. Constr. Manag. 2019, 19, 354-369. [CrossRef]

57. Banihashemi, S.; Hosseini, M.R.; Golizadeh, H.; Sankaran, S. Critical success factors (CSFs) for integration of sustainability into construction project management practices in developing countries. Int. J. Proj. Manag. 2017, 35, 1103-1119. [CrossRef]

58. Huemann, M.; Keegan, A.; Turner, J.R. Human resource management in the project-oriented company: A review. Int. J. Proj. Manag. 2007, 25, 315-323. [CrossRef]

59. Dziekoński, K. Application of classification trees for comparative analysis of construction project manager's competencies. Pol. J. Manag. Stud. 2016, 14, 40-50. [CrossRef]

60. Dziekoński, K. Project managers' competencies model for construction industry in Poland. Procedia Eng. 2017, 182, 174-181. [CrossRef]

61. Grzesik, K.; Piwowar-Sulej, K. Project Managers' Competencies and Leadership Styles from the Perspective of Organizations Functioning in Poland. J. Entrep. Manag. Innov. 2018, 14, 35-60. [CrossRef]

62. Podgórska, M.; Pichlak, M. Analysis of project managers' leadership competencies: Project success relation: What are the competencies of polish project leaders? Int. J. Manag. Proj. Bus. 2019, 12, 869-887. [CrossRef]

63. Kapliński, O. Development and usefulness of planning techniques and decision-making foundations on the example of construction enterprises in Poland. Technol. Econ. Dev. Econ. 2008, 14, 492-502. [CrossRef]

64. Dziadosz, A.; Rejment, M. Risk analysis in construction project-chosen methods. Procedia Eng. 2015, 122, 258-265. [CrossRef]

65. Gohar, A.S.; Khanzadi, M.; Farmani, M. Identifying and evaluating risks of construction projects in fuzzy environment: A case study in Iranian construction industry. Indian J. Sci. Technol. 2012, 5, 3593-3602. [CrossRef]

66. Chan, A.P.C.; Chan, D.W.M.; Chiang, Y.H.; Tang, B.S.; Chan, E.H.W.; Ho, K.S.K. Exploring critical success factors for partnering in construction projects. J. Constr. Eng. Manag. 2004, 130, 188-198. [CrossRef]

67. Kania, E.; Radziszewska-Zielina, E.; Śladowski, G. Communication and Information Flow in Polish Construction Projects. Sustainability 2020, 12, 9182. [CrossRef]

68. Kapliński, O.; Werner, W.; Kosecki, A.; Biernacki, J.; Kuczmarski, F. Current state and perspectives of research on construction management and mechanisation in Poland. J. Civ. Eng. Manag. 2002, 8, 221-230. [CrossRef]

69. Pasławski, J.; Jastrzab, T. Flexibility in Managing the Implementation of Construction Processes; Poznań University of Technology Publishing House: Poznań, Poland, 2009.

70. Połoński, M. Wiarygodność szacowanych kosztów planowanych inwestycji na tle barier w procesie inwestycyjnym. Acta Sci. Polonorum. Archit. 2007, 6, 35-41.

71. Leśniak, A. Skąd się biorą opóźnienia. Builder 2010, 1, 24-25.

72. Leśniak, A. Przyczyny opóźnień budowy w opinii wykonawców. Budownictwo 2012, 109.

73. Leśniak, A.; Plebankiewicz, A. Opóźnienia w robotach budowlanych. WSOWL Sci. Pap. 2010, 3, 332-339.

74. Sobotka, A.; Czarnigowska, A. Analysis of supply system models for planning construction project logistics. J. Civ. Eng. Manag. 2005, 11, 73-82. [CrossRef]

75. Sobieraj, J.; Metelski, D.; Nowak, P. The View of Construction Companies' Managers on the Impact of Economic, Environmental and Legal Policies on Investment Process Management. Arch. Civ. Eng. 2021, 67, 111-129. [CrossRef]

76. Jaśkowski, P.; Biruk, S. The Method for Improving Stability of Construction Project Schedules through Buffer Allocation: Statybos vykdymo grafiko stabilumo užtikrinimas paskirstant laiko rezervus. Technol. Econ. Dev. Econ. 2011, 17, 429-444. [CrossRef]

77. Sobieraj, J.; Metelski, D. The Impact of State Policies on Investment Project Management in Polish Industrial Construction Sector. J. Mod. Account. Audit. 2021, 17, 14-40. [CrossRef]

78. Leśniak, A.; Zima, K. Cost calculation of construction projects including sustainability factors using the Case Based Reasoning (CBR) method. Sustainability 2018, 10, 1608. [CrossRef]

79. Kulejewski, J. Directions of system solutions in the field of management of construction investment projects financed from public funds. In Problems Concerning Preparation and Implementation of Construction Projects, Proceedings of the Scientific Conference Dedicated to Construction Project Management, Puławy, Poland, 22-24 October 2008; Polish Association of Civil Engineers: Warsaw, Poland, 2008.

80. Sobieraj, J. Impact of spatial planning on the pre-investment phase of the development process in the residential construction field. Arch. Civil Eng. 2017, 63. [CrossRef]

81. Hsino, M.; Pasławski, J. Wprowadzenie elastyczności w zarządzaniu jakością na przykładzie betonowania. Bud. I Inżynieria Sr. 2011, 2, 289-292. 
82. Tracz, R. Strategia zarządzania przedsiębiorstwem budowlanym, etapy rozwoju i stan współczesny. Acta Sci. Pol. Archit. 2017, 16. [CrossRef]

83. Siemiatycki, M. The Theory and Practice of Infrastructure Public-Private Partnerships Revisited: The Case of the Transportation Sector. Available online: http:/ / www.ub.edu/graap/Final\%20Papers\%20PDF/Siemiatycki\%20Matti.pdf (accessed on 5 August 2021).

84. Sobieraj, J. Good public-private partnership practices. Bus. Econ. Org. 2011, 3, 64-71.

85. Wegrzyn, J. Research trends of public-private partnerships (PPPs) in Poland. Oeconomia Copernic. 2015, 6, 125-136. [CrossRef]

86. Wegrzyn, J. The Perception of Critical Success Factors for PPP Projects in Different Stakeholder Groups. Entrep. Bus. Econ. Rev. 2016, 4, 81-92. [CrossRef]

87. Skorupka, D. Identification and initial risk assessment of construction projects in Poland. J. Manag. Eng. 2008, 24, 120-127. [CrossRef]

88. Bizon-Górecka, J.; Górecki, J. Risk management in the Polish enterprises-Effects of research. In Strategies of Risk Management in the Enterprise; Bizon-Górecka, J., Ed.; TNOiK: Bydgoszcz-Ciechocinek, Poland, 2005.

89. Turskis, Z.; Gajzler, M.; Dziadosz, A. Reliability, risk management, and contingency of construction processes and projects. J. Civ. Eng. Manag. 2012, 18, 290-298. [CrossRef]

90. Szymański, P. Risk management in construction projects. Procedia Eng. 2017, 208, 174-182. [CrossRef]

91. Bryx, M. The Real Estate Industry. System and Functioning; Poltext Publishing House: Warsaw, Poland, 2006.

92. Grzywiński, J. Instrument Process in Compliance with Polish Construction Law; Furtek Komosa Aleksandrowicz Law Office Publishing House: Warsaw, Poland, 2015.

93. Górecki, J.; Diaz-Madronero, M. Who Risks and Wins?-Simulated Cost Variance in Sustainable Construction Projects. Sustainability 2020, 12, 3370. [CrossRef]

94. Michalak, J.; Michałowski, B. Understanding of Construction Product Assessment Issues and Sustainability among Investors, Architects, Contractors, and Sellers of Construction Products in Poland. Energies 2021, 14, 1941. [CrossRef]

95. Fragoso, T.M.; Bertoli, W.; Louzada, F. Bayesian model averaging: A systematic review and conceptual classification. Int. Stat. Rev. 2018, 86, 1-28. [CrossRef]

96. Banner, K.M.; Higgs, M.D. Considerations for assessing model averaging of regression coefficients. Ecol. Appl. 2017, 27, 78-93. [CrossRef]

97. Zeugner, S.; Feldkircher, M. Bayesian model averaging employing fixed and flexible priors: The BMS package for R. J. Stat. Softw. 2015, 68, 1-37. [CrossRef]

98. Hoeting, J.A.; Madigan, D.; Raftery, A.E.; Volinsky, C.T. Bayesian model averaging: A tutorial. Stat. Sci. 1999, 14, $382-401$.

99. Zellner, A. On Assessing Prior Distributions and Bayesian Regression Analysis with g-Prior Distributions. In Bayesian Inference and Decision Techniques: Es-Says in Honor of Bruno de Finetti; Goel, P., Zellner, A., Eds.; Elsevier Science Publishers: New York, NY, USA, 1986; pp. 233-243.

100. Fayol, H. General and Industrial Management; Sir Isaac Pitman \& Sons: London, UK, 1949.

101. Mintzberg, H. Five Ps for Strategy. In The Strategy Process; Mintzberg, H., Quinn, J.B., Eds.; Prentice Hall International Editions: Englewood Cliffs, NJ, USA, 1992; pp. 12-19.

102. Moral-Benito, E. Model averaging in economics: An overview. J. Econ. Surv. 2015, 29, 46-75. [CrossRef]

103. Juszczyk, M.; Leśniak, A.; Zima, K. ANN based approach for estimation of construction costs of sports fields. Complexity 2018, 7952434, 1-11. [CrossRef]

104. Buchowiecka, A.; Grzenia, A.; Felczykowska, A.; Sadowska, H.; Żeromska-Mielniczuk, D. Accident at Work in 2017; Statistical Office in Gdansk (Centre for Working Conditions Statistics): Gdańsk, Poland, 2018. 